\title{
The Late Devonian and Early Carboniferous ammonoids (Cephalopoda) from Milivojevića Kamenjar, Družetić (NW Serbia) and their stratigraphy
}

\author{
DIETER KORN \& MILAN N. SUDAR
}

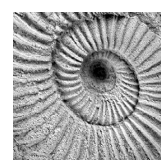

\begin{abstract}
The Late Devonian to Early Carboniferous olistolith near Družetić (north-western Serbia) contains the most species rich occurrence of Palaeozoic ammonoids known from the Balkan Peninsula. Four main faunal complexes are recorded, (1) a late Famennian assemblage with few clymeniids, (2) a species-poor indifferent Tournaisian assemblage, (3) two rather diverse early Late Viséan assemblages with about 15 species and (4) two latest Viséan/Serpukhovian assemblages with more than 20 species. The new genus Druzeticia and the following new species are described from the third faunal complex: Beyrichoceras jadarense, Ubites divnae, Ubites novaki, Entogonites serbicus, Druzeticia decens and Prolecanites stevanovici. The latest Viséan/Serpukhovian assemblages show very close relationships with the South Urals and both regions most probably belong to the same palaeogeographical realm. $\bullet$ Key words: Ammonoidea, Late Devonian, Early Carboniferous, Serbia, Družetić, stratigraphy.
\end{abstract}

KoRn, D. \& SudAR, M.N. 2016. The Late Devonian and Early Carboniferous ammonoids (Cephalopoda) from Milivojevića Kamenjar, Družetić (NW Serbia) and their stratigraphy. Bulletin of Geosciences 91(1), 187-220 (32 figures, appendix). Czech Geological Survey, Prague. ISSN 1214-1119. Manuscript received July 16, 2015; accepted in revised form December 18, 2015; published online March 15, 2016; issued March 17, 2016.

Dieter Korn (corresponding author), Museum für Naturkunde, Leibnitz Institute at the Humboldt University Berlin, Invalidenstraße 43, 10115 Berlin, Germany; dieter.korn@mfn-berlin.de•Milan N. Sudar, Serbian Academy of Sciences and Arts, Knez-Mihailova 35, 11000 Belgrade, Serbia; milan.sudar1946@gmail.com

Records of Palaeozoic ammonoids from the Balkan Peninsula are very rare, and they are usually limited to a few specimens and species-poor assemblages. A Late Viséan ammonoid assemblage found north of Prača near Sarajevo (Bosnia and Herzegovina) by the miner Grimmer and described by Kittl (1904a, b) was for a long time the most diverse assemblage known from the entire area. Preservation of this material, however, is rather poor and does not allow for a very detailed analysis (Kostić-Podgorska 1958). This assemblage was remarkable because of the occurrence of the peculiar species Entogonites grimmeri, an ammonoid with tetrangularly coiled inner whorls.

A second Palaeozoic ammonoid fauna was discovered by Renz (1910) near Attika (Greece), but this only contained the single species Pericleites atticus. The stratigraphical age of this species is still unclear; Ruzhencev \& Bogoslovskaya (1971) interpreted this as a Namurian species and described specimens from the South Urals, which they attributed to the same genus.

The discovery of a considerably diverse assemblage near Družetić (north-western Serbia; Fig. 1) in the late 1950's replaced Prača as the most diverse ammonoid assemblage of the Balkan Peninsula (Stevanović \&
Kullmann 1962) and has occupied this position for the past fifty years (Korn et al. 2010a, b). After the original description, a complete revision of the ammonoid descriptions had not been achieved and this will now be introduced here.

The revision presented here is mainly based on new collections, which leads to a significant widening of the spectrum of ammonoid species from this section. The largely in-situ collected material also allows for a correlation of the succession of ammonoid species with the conodont stratigraphy.

\section{Historical review}

The study of Carboniferous ammonoids from Serbia begins with the discovery of the Milivojevića Kamenjar section in the village Družetić in 1956 by Petar Stevanović. At that time, the Carboniferous sedimentary succession within the area was poorly known, and hence the olistolithic nature of the limestone occurrences of Družetić has not been discovered. In a first report, Stevanović (1962) described the ammonoid-bearing beds as cephalopod limestone. At the same time, Kullmann studied the ammonoid faunas, 


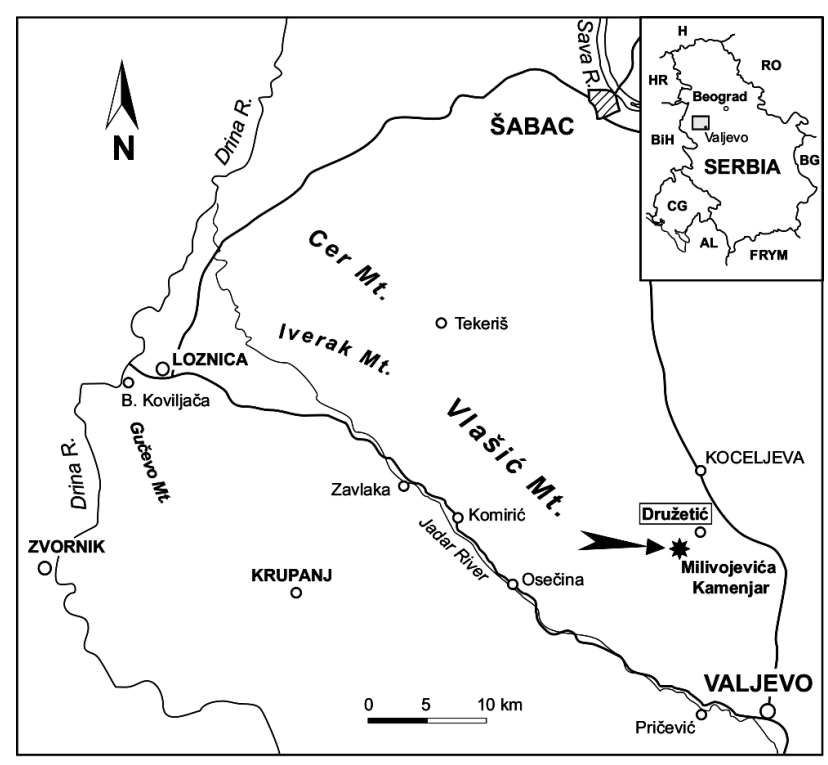

Figure 1. Location of the Milivojevića Kamenjar section (north-western Serbia; modified and simplified from Korn et al. 2010b).

which were presented in the context of stratigraphy and palaeogeography in a comprehensive monographic article (Stevanović \& Kullmann 1962). In their study, two ammonoid layers with moderately rich assemblages were separated:

From the "lower layer" (which is in fact the stratigraphically younger horizon and belongs in the latest Viséan to Serpukhovian, see below), Stevanović \& Kullmann (1962) listed the following species:

"Prionoceras (Irinoceras) stevanovici Kullmann, 1962", "Rhymmoceras gracilentum Ruzhencev, 1958", "Proshumardites (Proshumardites) serbicus Kullmann, 1962", "Proshumardites (Trigonoshumardites) wocklumerioides Kullmann, 1962", "Pronorites uralensis uralensis Karpinsky, 1889".

From the "upper layer" (which is in fact the stratigraphically older, early Late Viséan horizon), the authors listed the following species: "Cravenoceras cowlingense Bisat, 1932", "Gastrioceras (Branneroceras) branneri branneri Smith, 1896”.

Additionally, five species were reported to occur in both layers: "Cravenoceras arcticum subinvolutum Librovitch, 1938", "Nuculoceras crenistriatoide Kullmann, 1962", "Gastrioceras (Branneroceratoides) tetragonum Kullmann, 1962", "Eoasianites europaeus Kullmann, 1962", "Metacanites chancharensis (Ruzhencev, 1948)".

Stevanović \& Kullmann (1962) postulated two opinions about the stratigraphical age of these assemblages:

(1) Both layers have the same stratigraphical age.

(2) Both layers have a stratigraphical position in the "upper Eumorphoceras Stufe".

Already Ruzhencev \& Bogoslovskaya (1971, p. 37) commented on the taxonomic and stratigraphic characteristics of the faunas from Družetić and criticised several of the generic identifications, such as the attribution of specimens to Gastrioceras rather than to Entogonites. They attributed the aforementioned species to the genera Dombarocanites, Uralopronorites, Irinoceras, Entogonites, Pericleites, Cravenoceras, Glaphyrites, Nuculoceras and Rhymmoceras.

As will be shown below, both hypotheses by Stevanović \& Kullmann (1962) will be refuted. The reasons for the misinterpretations, on which the two hypotheses are founded, may be explained by the following:

1) Stevanović \& Kullmann (1962) obviously did not analyse the lithology of the limestone succession in great detail. Analysis of polished slabs or thin sections would have provided them with evidence (such as geopetal fabrics) for an inverted succession.

2) At the time of their studies, little was known about olistostromes; therefore Stevanović \& Kullmann (1962) obviously did not consider the possibility that the occurrence at Milivojevića Kamenjar represents a reworked limestone block with inverted stratigraphic succession. However, doubts on the postulation that the limestone at this outcrop are entirely of Namurian age were, at that time, already put forward by Ivan Filipović (personal communication), who found Late Devonian microfossils (styliolinids, ostracods) in nodular limestone horizons at the top of the outcrop. This argument was dismissed by Stevanović \& Kullmann (1962, footnotes on pp. 50 and 66), who insisted on a Namurian age for the entire outcrop on the basis of evidence from the ammonoid faunas.

3) The putative occurrence of some of the species [e.g., "Gastrioceras (Branneroceratoides) tetragonum"] in both layers (Stevanović \& Kullmann 1962, pp. 48, 65) led those authors to assume that there is no difference in age between the two horizons. However, this statement can easily be refuted. - One of the results of the new investigation of the Milivojevića Kamenjar site (e.g., Korn et al. 2010a, b) and its ammonoids is that not a single species was found to occur in both horizons. The significant stratigraphic difference between the two assemblages makes it very unlikely that there are species, which are present in both of them. Mixing of samples in the outcrop may have caused an erroneous record of some of the species in the "lower horizon". The species putatively occurring in both horizons were possibly the reason why J. Kullmann (in Stevanović \& Kullmann 1962, p. 65) concluded, "the difference between the two beds is insignificant according to their faunas" ("... Unterschied zwischen diesen beiden Schichten infaunistischer Hinsicht unbedeutend.”).

4) The palaeogeographical distribution of Carboniferous ammonoid faunas was not well known in the early 1960's. - The species list of Stevanović \& Kullmann (1962) shows that names of species from very distant regions have been used (Korn et al. 2010b, 2012), the South Urals (3 species), Novaya Zemlya (1), Northern England 
(1) and the American Midcontinent (1). A further six species have been newly described. On the basis of this, Stevanović \& Kullmann (1962, p. 86) concluded that the closest relationships are noticeable with the Urals. However, they also stated that the fauna from Družetić has an intermediate position between the "epicontinental and geosynclinal facies" of the Carboniferous occurrences in Europe.

5) The species-rich Viséan-Serpukhovian ammonoid assemblages from the South Urals were only fragmentarily described until the early 1960's (e.g., Ruzhencev 1947, 1949, 1956; Librovitch 1957; Ruzhencev 1958). Only with the voluminous monographs by Ruzhencev \& Bogoslovskaya $(1971,1978)$ did it become much easier to interpret less well-preserved material like the specimens from Družetić. - Several of the stratigraphically younger species newly described by Stevanović \& Kullmann (1962) from Družetić were already known from the South Urals, but this was not fully recognised by the authors.

\section{The rock succession of the Milivojevića Kamenjar section}

The geological setting of the Milivojevića Kamenjar site has been described in detail by Korn et al. (2010a, b). At Milivojevića Kamenjar in Družetić, approximately 15 metres of sedimentary rocks, nearly exclusively carbonates, are exposed. The inverted bedding planes are inclined with 10 to $25^{\circ}$ in a south-western direction. The succession can be subdivided into five units, in descending order (i.e. stratigraphically from older to younger) in the outcrop (Fig. 2):

Unit 1. Dark-grey, nodular flaser limestone (>2 m) with high shale content, only poorly exposed. The limestone nodules and their macrofossil content are strongly deformed.

Unit 2. Grey, bedded and partly nodular limestone with minor shale content $(0.95 \mathrm{~m})$.

Unit 3. Dark-grey or light-grey, partly coarse-grained bedded limestone with high fossil content $(0.65 \mathrm{~m})$. Two fossil samples (DRZ1 and DRZ2, separated by a distance of about $20 \mathrm{~cm}$ ) were taken from this "upper" (i.e., stratigraphically older) portion of succession. Particularly the stratigraphically younger sample DRZ1 is a coquina with a mass occurrence of ammonoids, but most of the specimens larger than $10 \mathrm{~mm}$ are crushed.

Unit 4. Light-grey, thick-bedded or almost non-bedded non-fossiliferous micritic limestone $(8.6 \mathrm{~m})$.

Unit 5. Grey, well-bedded micritic nodular limestone ( $2.80 \mathrm{~m}$ are currently exposed) with minor shale content. From this unit, a number of ammonoid samples were obtained. The occurrence of macrofossils is very patchy; in some cases coquinas packed with ammonoids occur in more sparitic portions at several positions of the section.

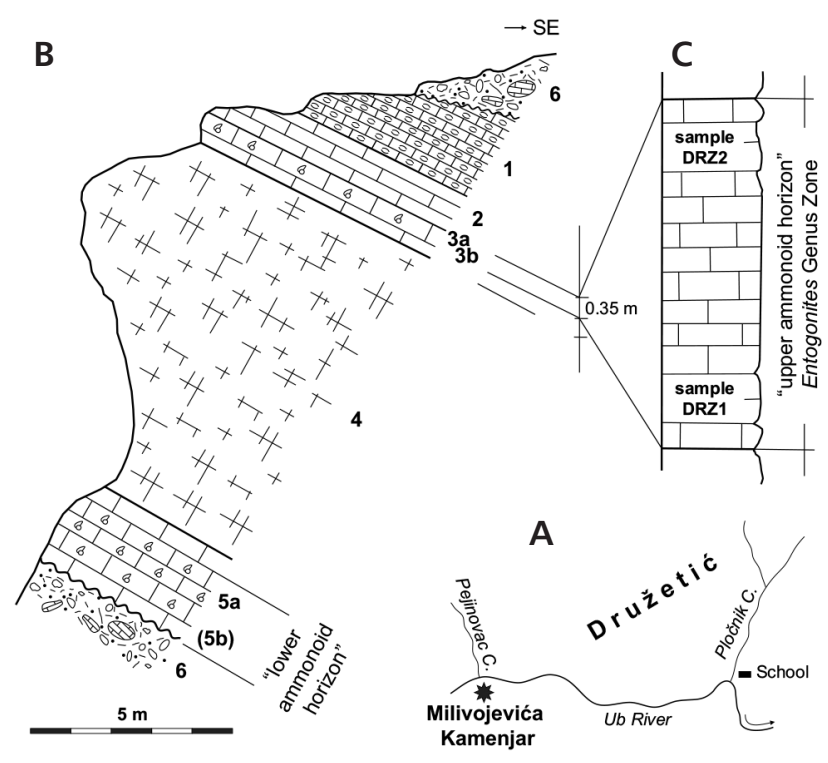

Figure 2. Milivojevića Kamenjar section (from Korn et al. 2010b). - A - sketch of the geographical position in the area of Družetić village (Jadar Block, Vardar Zone, NW Serbia). • B - section of the Milivojevića Kamenjar olistolith. Legend: Unit 1 - dark grey nodular limestones with thin shaly beds (Famennian according to Filipović 1995); Unit 2 - grey bedded nodular limestones (Tournaisian according to Filipović 1995); Unit 3 - grey bedded limestones with ammonoids (Namurian "upper fossiliferous layer" according to Stevanović \& Kullmann 1962; early late Viséan according to Korn et al. 2010b); Unit 4 - grey massive, thick-bedded and bedded limestones (Viséan according to Filipović 1995); Unit 5 grey bedded limestones with ammonoids (Namurian "lower fossiliferous layer" according to Stevanović \& Kullmann 1962; Lower Serpukhovian according to Filipović 1995; latest Viséan to earliest Serpukhovian in Korn et al. 2010b); 6 - Podolskian olistostromal deposits of the Ivovik Formation (Filipović 1995). • C - detail of the upper part of unit 3 ("upper ammonoid horizon", Entogonites Genus Zone of the early late Viséan in Korn et al. 2010b).

\section{Material}

More than 800 newly collected specimens, stored in the Cephalopod collection of the Museum für Naturkunde, Berlin (MB.C. prefix) are available for study besides about 120 ammonoid specimens stored in the Natural History Museum, Belgrade (BEO600-551.73:592-prefix). This material comes from four main intervals of the section:

Unit 1. - The nodular or flaser limestone of this unit is strongly affected by lateral and vertical tectonic deformation, and hence the fossil content is poorly preserved. Only some of the fragmentarily preserved ammonoids can be assigned to distinct genera and species. This material, which consists of 14 specimens, has a latest Famennian (Late Devonian) age. The assemblage can be assigned to the early Wocklumeria Stufe:

Linguaclymenia similis (Münster, 1839) 1 specimen Linguaclymenia sp.
1 specimen
1 specimen 
kosmoclymeniid indet.

Cymaclymenia sp.

Mimimitoceras sp.

6 specimens

5 specimens

1 specimen

Unit 2. - Few ammonoids of unspecified Tournaisian age were collected from a single horizon at the top of the unit:

\section{Imitoceras sp.}

2 specimens

Unit 3. - Ammonoids were collected from two horizons, which differ only slightly in the species composition of the assemblages but markedly in the numbers of the individual specimens per species.

(a) The stratigraphically older horizon is a dark-grey fossil-rich micrite, in which concentrations of fossils, particularly of ammonoids, occur sporadically. The fossils are well preserved but often fragmented caused by sedimentary transport. Most of the 310 specimens from this horizon are very small (less than $10 \mathrm{~mm}$ ), but some specimens possess sizes of up to $80 \mathrm{~mm}$. All are laterally deformed; deformation affected particularly the body chambers of the specimens. In specimens from this horizon, shell ornament is often very well preserved. The following species were newly collected from this horizon, which can clearly be attributed to the Entogonites Genus zone (Fig. 3):

Beyrichoceratoides sp.

Bollandites sp.

Bollandoceras sp.

Beyrichoceras jadarense sp. nov.

Calygirtyoceras sp.

Ubites filipovici Korn \& Sudar, 2010

Ubites divnae sp. nov.

Ubites novaki sp. nov.

Entogonites grimmeri (Kittl, 1904)

Entogonites tetragonus (Kullmann, 1962)

Druzeticia decens gen et sp. nov.

Nomismoceras sp.

Prolecanites stevanovici sp. nov.

Pronorites sp.

indet. juvenile specimens

(b) The stratigraphically younger of the two horizons is a light-grey sparite of about $30 \mathrm{~cm}$ thickness. This horizon is very rich in fossils, particularly in ammonoids, of which more than 350 specimens are available. Most of the specimens are very small (juvenile and adult specimens of
Entogonites and juveniles of other genera). Details of the shell ornament are rarely preserved in this coarse-grained limestone, but deformation of the specimens is not significant. Most of the material attributed to the "upper horizon" by Stevanović \& Kullmann (1962) derives from this horizon. The following species were newly collected from this rock unit, which can clearly be attributed to the Entogonites Genus zone:

Beyrichoceratoides sp.

1 specimen

Bollandites sp.

Beyrichoceras crenistriatoide

(Kullmann, 1962)

Ubites filipovici Korn \& Sudar, 2010

Ubites divnae sp. nov.

Ubites novaki sp. nov.

Entogonites grimmeri (Kittl, 1904)

Entogonites serbicus sp. nov.

2 specimens

Entogonites tetragonus (Kullmann, 1962)

12 specimens

6 specimens

2 specimens

12 specimens

44 specimens

8 specimens

Entogonites sp.

Nomismoceras sp.

Druzeticia decens gen. et sp. nov.

Prolecanites stevanovici sp. nov.

Pronorites sp.

indet. juvenile specimens

55 specimens

11 specimens

6 specimens

2 specimens

70 specimens

1 specimen

19 specimens

Unit 5. - Ammonoids occur sporadically within an interval of about three metres thickness, but it is very difficult to obtain in-situ samples with high fossil content. Therefore, many float blocks with the same lithology were examined to acquire a larger amount of ammonoid specimens. The fossils occur usually in micritic, slightly nodular grey limestone that contains numerous limonitic veins, pressure solution surfaces. Most of the ammonoid specimens are strongly deformed or sheared and this deformation affected the body chambers of the specimens in particular. The phragmocones are usually filled with coarse calcite cement, which has often destroyed all inner structures such as shell walls and septa. Shell surfaces are often poorly preserved because of recrystallization and pressure solution, and hence species determination is difficult in many of these specimens. It is apparent that two complexes are represented (Fig. 3):

(a) The stratigraphically older complex is characterised by light grey to medium grey, partly sparitic limestone with numerous limonitic and sideritic veins as well as pressure solution surfaces. From this complex, 105 newly collected specimens (in-situ and float collections) are available for study. The assemblage has a latest Viséan to early

Figure 3. Latest Famennian to Serpukhovian chronostratigraphy, ammonoid zonation for the Rhenish Mountains, Central European and South Urals ammonoid genus zones (after Ruzhencev \& Bogoslovskaya 1971, Korn et al. 2007), and position of the ammonoid-bearing horizons in the Milivojevića Kamenjar olistolith. FAM. - Famennian; SERP. - Serpukhovian; Ar. - Arundian; Pndl. - Pendleian; Arns. - Arnsbergian. 


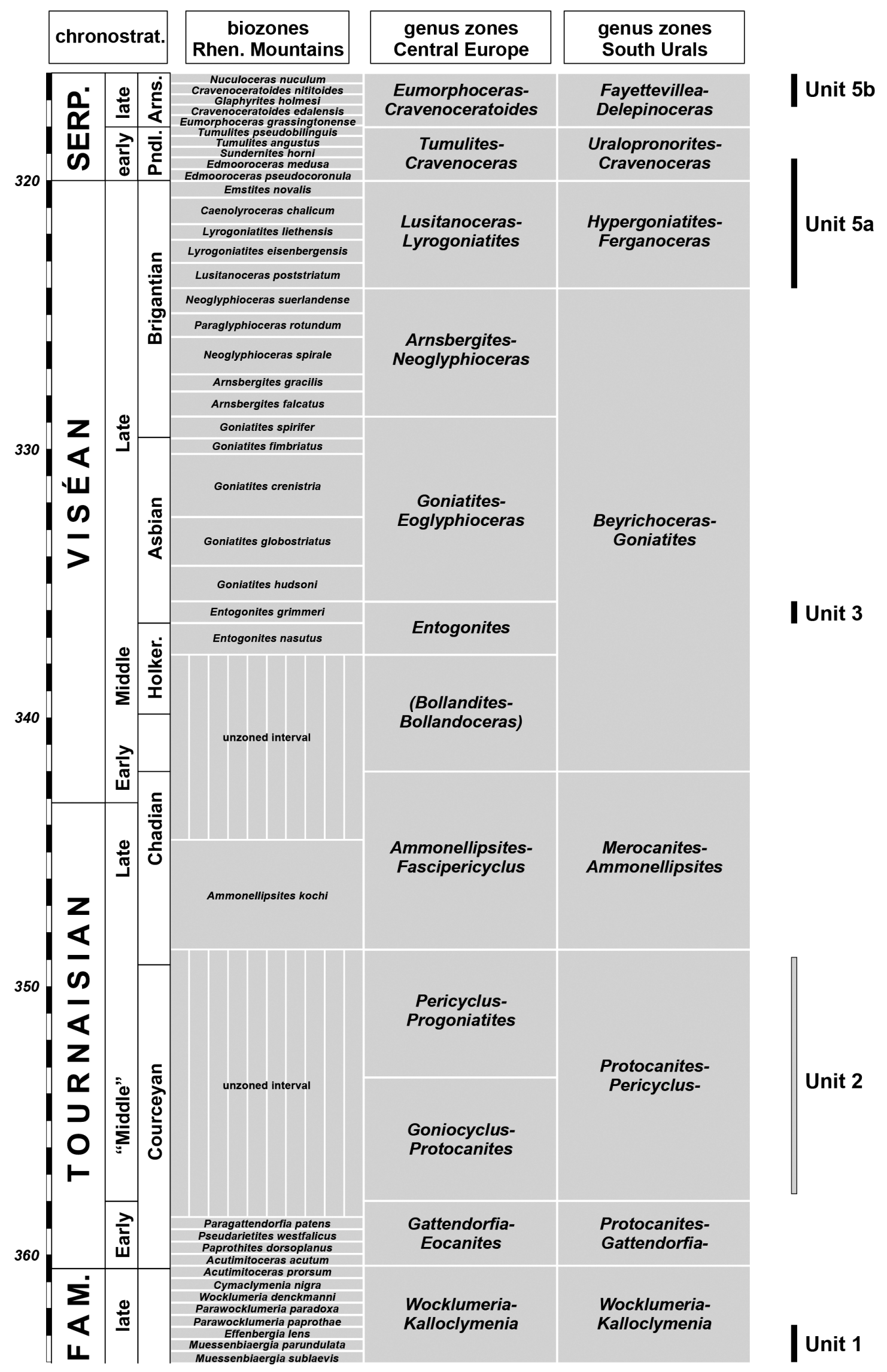



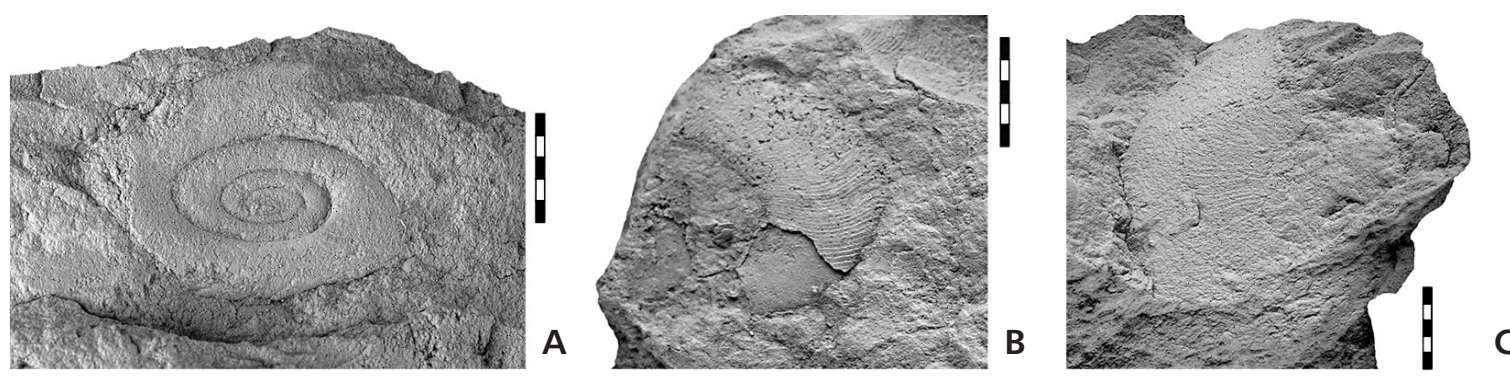

Figure 4. Representatives of clymeniids from Družetić; lateral views. • A - Linguaclymenia similis (Münster, 1839), specimen MB.C.25587 from loose block 2010-A; × 2.0. • B - Cymaclymenia sp., specimen MB.C.25586 from sample 2009-D32; × 2.0. • C - Cymaclymenia sp., specimen MB.C.25592 from loose block 2012-10; $\times 1.5$.

Serpukhovian age. Most of the fossil content is strongly deformed; the assemblage is represented by the following species from new collections:
Irinoceras arcuatum Ruzhencev, 1947

Hypergoniatites sp.

Dombarites falcatoides Ruzhencev

\& Bogoslovskaya, 1970

Dombarites liratus Ruzhencev

\& Bogoslovskaya, 1971

Platygoniatites molaris Ruzhencev, 1956

Platygoniatites omniliratus Ruzhencev

\& Bogoslovskaya, 1971

Cravenoceras sp.

Lyrogoniatites tener Ruzhencev

\& Bogoslovskaya, 1971

Lyrogoniatites sp.

Pachylyroceras sp.

Uralyroceras $\mathrm{sp}$.

Tympanoceras sp.

Neoglyphioceras baccans Ruzhencev

\& Bogoslovskaya, 1971

Neoglyphioceras litvinovichae Ruzhencev

\& Bogoslovskaya, 1971

Neoglyphioceras sp.

Lusitanites concavus Ruzhencev

Ophilyroceras tersum Ruzhencev

\& Bogoslovskaya, 1971

Dombarocanites catillus Ruzhencev

\& Bogoslovskaya, 1971

Praedaraelites aktubensis Ruzhencev

\& Bogoslovskaya, 1971

Uralopronorites mirus Librovitch, 1949
\& Bogoslovskaya, 1971
7 specimens

1 specimen

17 specimens

6 specimens

5 specimens

6 specimens

1 specimen

2 specimens

1 specimen

3 specimens

1 specimen

1 specimen

26 specimens

1 specimen

5 specimens

4 specimens

4 specimens

6 specimens

4 specimens

3 specimens contains the following ammonoid assemblage from new collections:

Proshumardites uralicus Librovitch, 19411 specimen Rhymmoceras gracilentum Ruzhencev, 19581 specimen

\section{Systematic palaeontology}

Order Clymeniida Hyatt, 1884

Suborder Clymeniina Hyatt, 1884

Superfamily Clymeniaceae Edwards, 1849

Family Kosmoclymeniidae Korn \& Price, 1987

Subfamily Kosmoclymeniinae Korn \& Price, 1987

\section{Genus Linguaclymenia Korn \& Price, 1987}

\section{Linguaclymenia similis (Münster, 1839)}

Figure 4A

1839 Clymenia similis sp. nov.; Münster; p. 11.

1987 Kosmoclymenia (Linguaclymenia) similis (Münster). - Korn \& Price, p. 47, pl. 7, figs 53-55.

2002 Linguaclymenia similis (Münster). - Korn \& Klug, p. 253 , text-figs $221 \mathrm{j}, 222 \mathrm{c}, 223 \mathrm{i}$.

Material. - One deformed specimen.

Description. - MB.C. 25587 is a specimen of about $12 \mathrm{~mm}$ conch diameter (Fig. 4A). It is a laterally deformed, subevolute conch (uw/dm $\sim 0.42$ ) with rounded flanks and a ventrolateral groove at the end of growth. It displays coarse biconvex growth lines with a high ventrolateral projection typical for the species.

Remarks. - This single specimen is the only clymeniid from Družetić and probably the first from the entire Balkan Peninsula that can be determined to the species level. There are some other specimens, but because of their poor preservation they can only be determined as either Linguaclymenia sp. or Kosmoclymeniidae indet. 
Suborder Cyrtoclymeniina Korn, 2002

Superfamily Cyrtoclymeniaceae Hyatt, 1884

Family Cymaclymeniidae Hyatt, 1884

Subfamily Cymaclymeniinae Hyatt, 1884

\section{Genus Cymaclymenia Hyatt, 1884}

\section{Cymaclymenia sp.}

Figure 4B, C

Material. - Five fragmentary specimens, which because of their poor preservation can not be attributed to a distinct species.

Remarks. - Specimens MB.C.25586 and MB.C.25592.1 are fragments of specimens with about 15 and $20 \mathrm{~mm}$ conch diameter, which cannot be determined to the species level (Fig. 4B, C). According to the rather coarse growth lines and the lack of umbilical riblets it is close to $C$. striata (Münster). Specimen MB.C.25592.1 is an internal mould that shows rather strong protracting constrictions on the flank; in this character it resembles C. semistriata (Münster).

Order Goniatitida Hyatt, 1884

Suborder Tornoceratina Wedekind, 1914

Superfamily Prionocerataceae Hyatt, 1884

Family Prionoceratidae Hyatt, 1884

Subfamily Imitoceratinae Ruzhencev, 1950

\section{Genus Imitoceras Schindewolf, 1923}

\section{Imitoceras sp.}

Figure 5

Material. - Two specimens with about $30 \mathrm{~mm}$ conch diameter.

Description. - The poorly preserved specimen MB.C.25595.1 is slightly distorted and has $30 \mathrm{~mm}$ conch diameter. It is thickly discoidal (ww/dm $\sim 0.55$ ) with a closed umbilicus and a whorl expansion rate of 2.05. The suture line possesses a pouched $\mathrm{E}$ lobe that is less deep as the asymmetric A lobe. Both lobes are separated by an asymmetric, ventrally inclined ventrolateral saddle (Fig. 5).

Specimen MB.C.25595.2 is similar in size but somewhat crushed. It shows the shell surface, which is smooth except for barely visible, very delicate growth lines with convex course.

Remarks. - The material differs from most of the other species of the genus, such as I. rotatorium (de Koninck) by the relatively deep but less strongly pouched external lobe. The conch shape also differs because the specimen described
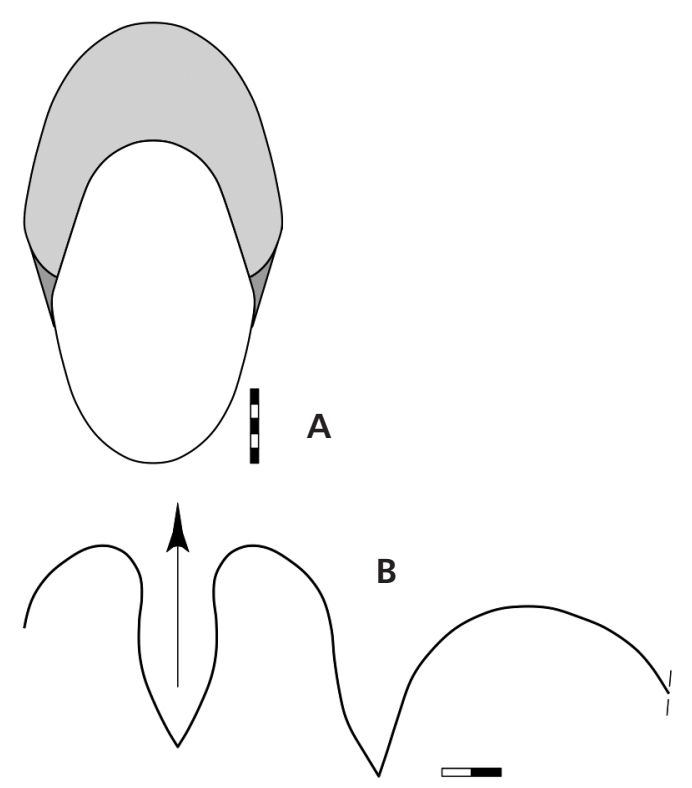

Figure 5. Imitoceras sp. specimen MB.C.25595.1 from Družetić; sample 2008-DRZ3. • A - dorsal view; × 1.5. • B - suture line, at $27 \mathrm{~mm} \mathrm{dm}$, $17 \mathrm{~mm}$ ww, $17.5 \mathrm{~mm}$ wh; $\times 3.0$.

here has a rather low coiling rate (WER 2.05), which is higher in most of the other species.

\section{Genus Irinoceras Ruzhencev, 1947}

\section{Irinoceras arcuatum Ruzhencev, 1947} Figure 6

1947 Irinoceras arcuatum sp. nov.; Ruzhencev, p. 283, text-figs $1,2 \mathrm{~b}, \mathrm{c}$.

1962 Prionoceras (Irinoceras) stevanovici Kullmann sp. nov.; Kullmann in Stevanović \& Kullmann, p. 73, pl. 1, fig. 1, text-fig. 1a, b.

1971 Irinoceras stevanovici (Kullmann). - Ruzhencev \& Bogoslovskaya, p. 37.

1971 Irinoceras arcuatum Ruzhencev. - Ruzhencev \& Bogoslovskaya, p. 150, pl. 3, figs 6, 7, pl. 6, fig. 1, text-fig. 16.

Material. - Seven specimens, ranging from $13 \mathrm{~mm}$ conch diameter (only one complete specimen) to fragments of specimens with $80 \mathrm{~mm}$ diameter, from new collections. Additionally four specimens in the Natural History $\mathrm{Mu}-$ seum, Belgrade.

Description. - Holotype BEO600-551.73:592-453 of "Prionoceras (Irinoceras) stevanovici" (Kullmann in Stevanović \& Kullmann 1962, pl. 1, fig. 1) is an undistorted specimen with $17 \mathrm{~mm}$ conch diameter. The specimen is thinly pachyconic $(\mathrm{ww} / \mathrm{dm}=0.62)$ with a nearly closed umbilicus 

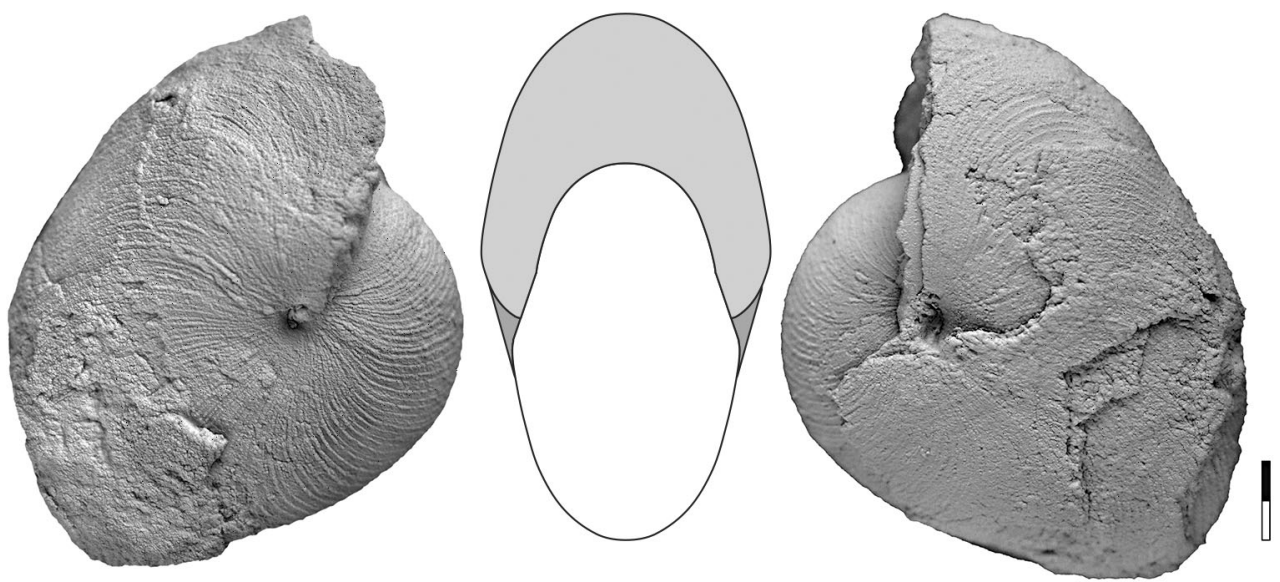

Figure 6. Irinoceras arcuatum Ruzhencev, 1947 from Družetić; lateral and dorsal views of specimen MB.C.25688 from sample 2009-A; × 4.

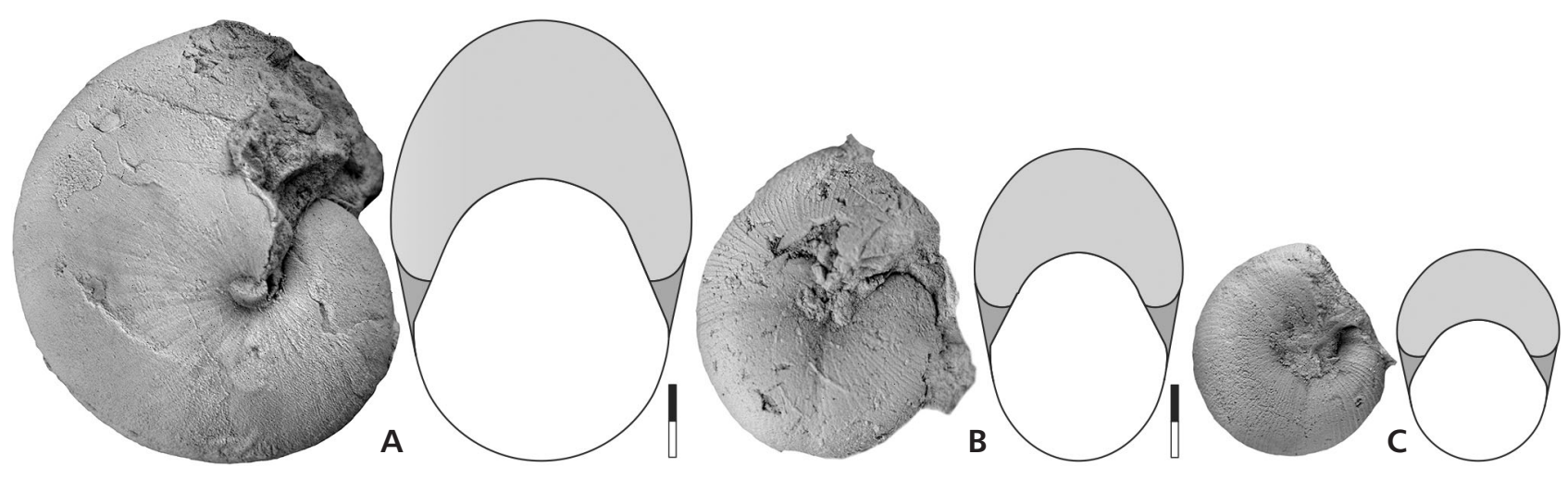

Figure 7. Beyrichoceratoides sp. from Družetić; lateral and dorsal views; all × 4.0. $\bullet$ A - specimen MB.C.25598 from sample 2008-DRZ1. • B - specimen MB.C.25669.1 from sample 2009-DRZ2. • C - specimen MB.C.25669.2 from sample 2009-DRZ2.

(uw/dm =0.05), a high aperture $(\mathrm{WER}=2.20)$ and a broadly rounded venter. It is rather well preserved with suture line and shell ornament visible. The ornament has lamellose coarse growth lines forming a low ventrolateral projection and a deep ventral sinus; the growth lines bifurcate on the inner flanks into two separate finer branches. There are no constrictions visible. The suture line possesses a strongly pouched external lobe and an asymmetric adventive lobe.

The smaller specimen MB.C.25688 (Fig. 6) has, at $13 \mathrm{~mm}$ conch diameter, similar conch proportions but is a little more slender (ww/dm 0.59). The ornament has lamellar growth lines that bifurcate on the inner flanks and form a very deep ventral sinus.

Discussion. - There is no real reason for a separation of the two species Irinoceras arcuatum and I. stevanovici. The slightly open umbilicus in the latter species is mainly caused by coarse preparation of the umbilicus and removal of the shell material in the holotype. In terms of the conch proportions, shell ornament and also the suture line, both species cannot be separated.
Superfamily Pericyclaceae Hyatt, 1900

Family Muensteroceratidae Librovitch, 1957

\section{Genus Beyrichoceratoides Bisat, 1924}

\section{Beyrichoceratoides sp.}

Figure 7

Material. - 14 specimens; conch diameter up to $12 \mathrm{~mm}$. While the shell ornament is well preserved in the material, a suture line is not visible.

Description. - Specimen MB.C.25598 (Fig. 7A) is rather well preserved and shows the conch proportions and the ornament at $12 \mathrm{~mm}$ conch diameter. The conch is thinly pachyconic (ww/dm $=0.68)$ with a nearly closed umbilicus (uw/dm = 0.05 ), a rounded umbilical margin and a broadly rounded venter. The ornament consists of very delicate growth lines, which extend with a low dorsolateral projection, a higher ventrolateral projection and a moderately deep ventral sinus.

The smaller specimens MB.C.25669.1 (8.5 mm dm; Fig. 7B) and MB.C.25669.2 (5.6 mm dm; Fig. 7C) have 


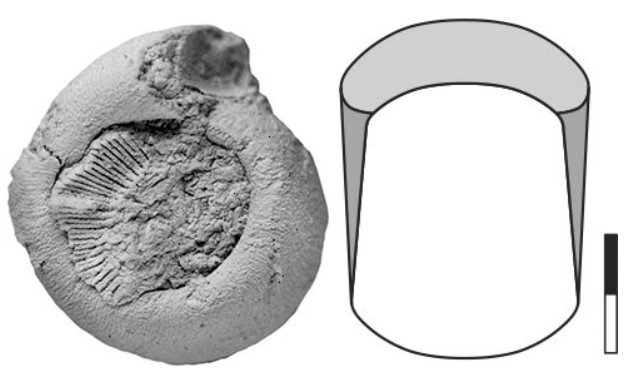

Figure 8. Bollandites sp. from Družetić; lateral and dorsal views of specimen MB.C.25634 from float block 2010-DRZ1; × 4.0.

similar conch proportions but differ from specimen MB.C.25598 in the coarser growth lines.

Family Maxigoniatitidae Korn, Klug \& Mapes, 1999

\section{Genus Bollandites Bisat, 1952}

\section{Bollandites sp.}

Figure 8

1962 Cravenoceras arcticum subinvolutum Librovitch. Kullmann in Stevanović \& Kullmann, p. 79, pl. 1, fig. 4.

1962 Eoasianites (Eoasianites) europaeus Kullmann n. sp.?; Kullmann in Stevanović \& Kullmann, p. 94, pl. 2, fig. 9.

Material. - Three specimens; conch diameter up to $8 \mathrm{~mm}$ from new collections. Additionally, three specimens in the Natural History Museum, Belgrade.

Description. - Specimen BE0600-551.73:592-474 is a slightly deformed specimen with $12 \mathrm{~mm}$ conch diameter. It is thickly pachyconic (ww/mm $\sim 0.80)$ and subevolute (uw/mm $\sim 0.35$ ) with a steep umbilical wall and a very wide and broadly rounded venter. The ornament shows fine growth lines with a shallow lateral sinus and a broad ventral projection. The suture line is barely visible with a very narrow external lobe and a broadly rounded ventrolateral saddle (broader than in text-fig. 3b of Kullmann in Stevanović \& Kullmann 1962).

Specimen MB.C.25634 is a small specimen with $5.4 \mathrm{~mm}$ conch diameter (Fig. 8). It is thickly pachyconic $(\mathrm{ww} / \mathrm{mm}=0.75)$ and evolute $(\mathrm{uw} / \mathrm{mm}=0.50)$ with a narrowly rounded umbilical margin that delimits the broad venter. The specimen has rather coarse lamellar growth lines, which form a lateral sinus on the umbilical wall and form a broad and low ventral projection.

Discussion. - It is clear that the specimens, for morphologi-

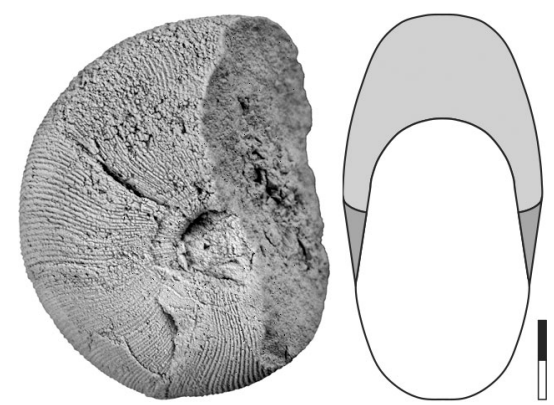

Figure 9. Bollandoceras sp. from Družetić; lateral and dorsal views of specimen MB.C.25680 from sample 2009-DRZ2; × 4.0.

cal and also stratigraphical reasons, cannot be assigned to Cravenoceras. The small individuals closely resemble juvenile material of the genus Bollandites particularly known from the British Isles (Korn \& Tilsley 2006). The small specimens have, with their wide umbilicus and broad flattened venter, also some resemblance with juvenile specimens of the genus Calygirtyoceras.

\section{Genus Bollandoceras Bisat, 1952}

\section{Bollandoceras sp.}

Figure 9

Material. - One specimen.

Description. - Specimen MB.C.25680 has a conch nearly $10 \mathrm{~mm}$ in diameter and is thickly discoidal and narrowly umbilicate (ww/dm $\sim 0.55$; uw/dm $\sim 0.25$ ) with subparallel flanks and a broadly rounded venter. The ornament has lamellar growth lines with biconvex course (Fig. 9).

\section{Genus Beyrichoceras Foord, 1903}

Beyrichoceras jadarense sp. nov. Figure 10A-C

Holotype. - Specimen MB.C.25668; illustrated here in Fig. 10A.

Type locality and horizon. - Milivojevića Kamenjar site in Družetić (NW Serbia); sample 2009-DRZ2, Ubites filipovici horizon, Entogonites Genus Zone.

Material. - 10 moderately well preserved but often strongly deformed specimens; conch diameter up to $70 \mathrm{~mm}$.

Etymology. - Named after the Jadar River area, the region with the type locality. 
Diagnosis. - Species of Beyrichoceras with thinly pachyconic conch (ww/dm $\sim 0.60)$ and very narrow umbilicus (uw/dm $\sim 0.05$ ) at $20 \mathrm{~mm}$ conch diameter; conch discoidal (ww/dm 0.45) with very narrow umbilicus (uw/dm $0.05)$ at $40 \mathrm{~mm} \mathrm{dm}$. Umbilical margin narrowly rounded. Ornament with about 200 fine spiral lines forming a spider-web pattern; growth lines biconvex already at $15 \mathrm{~mm} \mathrm{dm}$.

Description. - Specimen MB.C.25668 is a strongly deformed but otherwise rather well preserved specimen of about $43 \mathrm{~mm}$ conch diameter (Fig. 10A). The conch is discoidal and involute (ww/dm $\sim 0.45$; uw/dm $\sim 0.05$ ) with an umbilicus that appears to open slightly in the penultimate volution. Most of the specimen shows steinkern preservation, but shell remains are also preserved. The shell surface is covered by delicate spiral lines; the steinkern shows a barely visible, very shallow constriction. Only a small part of the suture line is visible; it shows a V-shaped adventive lobe with weakly sinuous flanks.

Specimen MB.C.25686 is another deformed specimen with about $40 \mathrm{~mm}$ conch diameter (Fig. 10B). It is fully covered with well-preserved shell material, which is ornamented by delicate spiral lines (about 100 from umbilicus to midventer) and even finer, biconvex growth lines. These growth lines possess a low dorsolateral projection, a very shallow lateral sinus, a low ventrolateral projection and a shallow ventral sinus.

The smaller specimen MB.C.25668.2 $(\sim 20 \mathrm{~mm} \mathrm{dm})$ is also strongly deformed but allows the reconstruction of conch proportions (Fig. 10C). It is thinly pachyconic (ww/dm $\sim 0.60$ ) with an almost closed umbilicus. The entire specimen is covered with shell material and the main component of the ornament is spiral ornamentation (about 200 spirals from umbilicus to umbilicus), which forms a spider-web pattern. The spirals are usually less wide than their interspaces but coarser than the fine growth lines. It is noticeable that the spirals are already perfectly developed at the beginning of the last preserved volution, i.e., at an approximate conch diameter of $15 \mathrm{~mm}$. Already at this stage and thereafter, the growth lines show a biconvex course with low dorsolateral and ventrolateral projections and a deeper ventral sinus.

Discussion. - The new species differs from the other Serbian species $B$. crenistriatoide (compare Fig. 10D) in the early presence (already at $15 \mathrm{~mm}$ conch diameter) of spiral ornament together with a biconvex course of the growth lines. In this growth stage, $B$. crenistriatoide still has predominant growth lines with a ventral projection.

Other species with a dense spiral ornament are B. araneum Nicolaus and B. delicatum Bisat, which have similar conch proportions, but the first species has a spider-web like spiral ornamentation, which is much less pronounced than that seen in the new species. The second species differs in the much finer spiral ornament. Most of the other species of the genus possess a stouter conch. Another criterion to separate the new species from the other species of the genus is the low ventrolateral projection of the growth lines, which in the other species is much more pronounced than the dorsolateral projection.

Beyrichoceras crenistriatoide (Kullmann, 1962) Figure 10D, E

1962 Nuculoceras crenistriatoide Kullmann sp. nov.; Kullmann in Stevanović \& Kullmann, p. 82, pl. 1, figs 5,6 .

Holotype. - Specimen BEO600-551.73:592-483 (Natural History Museum, Belgrade); illustrated by Stevanović \& Kullmann (1962, pl. 1, fig. 5).

Type locality and horizon. - Milivojevića Kamenjar site in Družetić (NW Serbia); "upper horizon" of Stevanović \& Kullmann (1962), probably Entogonites tetragonus horizon, Entogonites Genus Zone.

Material. - 12 specimens in the new collection with conch diameters up to $21 \mathrm{~mm}$. Additionally about 12 specimens in the Natural History Museum, Belgrade.

Diagnosis. - Species of Beyrichoceras with a thinly pachyconic, involute conch $(\mathrm{ww} / \mathrm{dm} \sim 0.70$; uw/dm $\sim 0.05)$ at 12-20 mm dm; aperture low (WER 1.65). Shell ornament with crenulated growth lines up to $18 \mathrm{~mm}$ conch diameter, thereafter fine spiral lines. Course of the growth lines with shallow lateral sinus and low and wide ventral projection.

Description. - Holotype BEO600-551.73:592-483 (Kullmann in Stevanović \& Kullmann 1962, pl. 1, fig. 5) is a slightly distorted specimen with a maximum diameter of almost $16 \mathrm{~mm}$. At $12 \mathrm{~mm}$ conch diameter, it is thinly pachyconic (ww/dm $\sim 0.70$ ) with a nearly closed umbilicus (uw/dm 0.05). The specimen is completely covered with shell, which shows very fine growth lines with clear lateral sinus and a flat, moderately high ventral projection. A suture line is not visible. The conch is filled with dark-grey calcite cement and the shell is dark brown; it most probably comes from the Entogonites tetragonus horizon.

Specimen MB.C.25650.1 is a rather well preserved and only slightly deformed specimen with $21 \mathrm{~mm}$ conch diameter (Fig. 10D). It is thinly pachyconic (ww/dm 0.70) and involute (uw/dm 0.05) with a low aperture (WER 1.65). Flanks and venter are broadly rounded. Most of the specimen is covered with shell material, which shows a change in the ornament during the last preserved volution. At the 

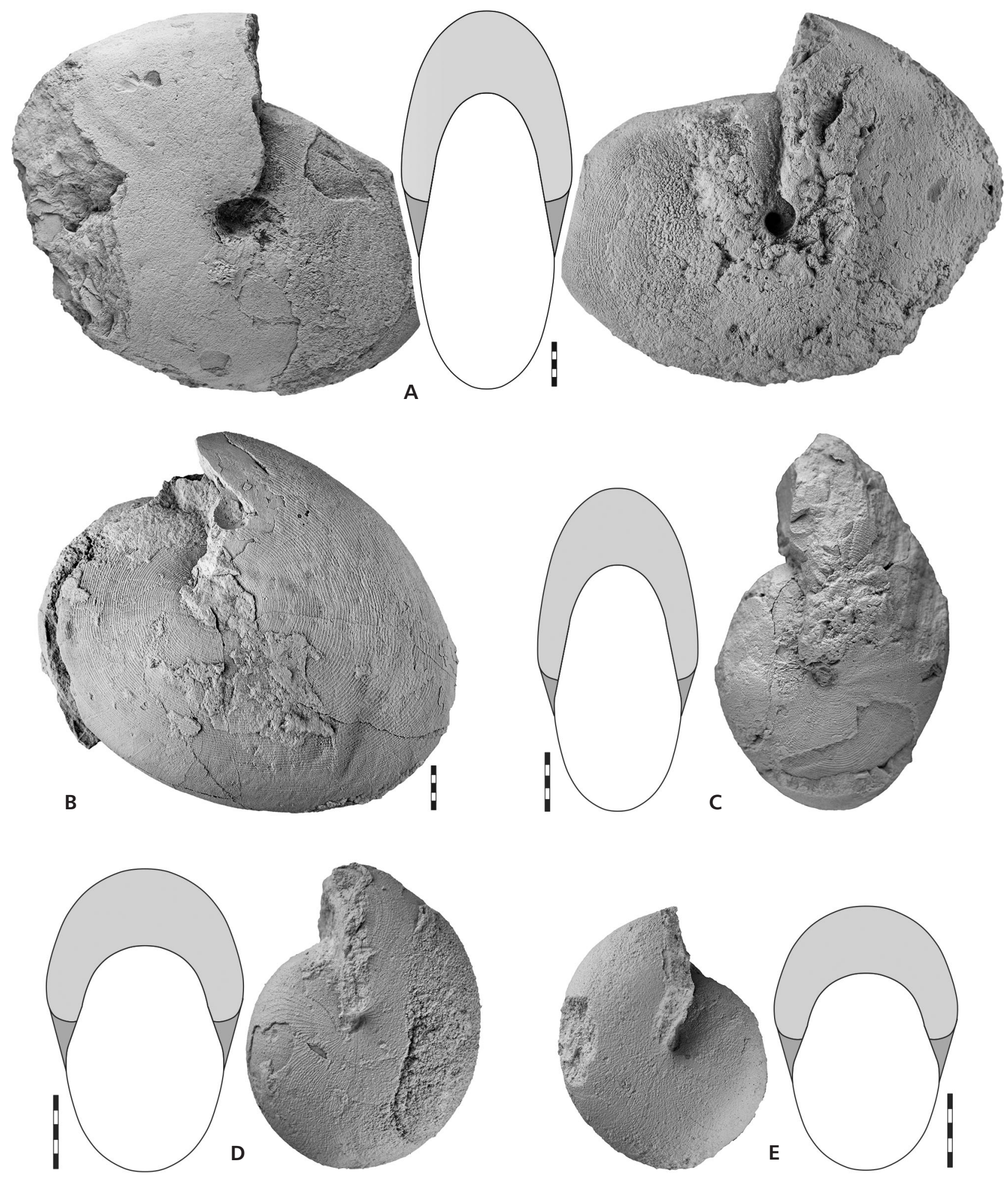

Figure 10. Representatives of the genus Beyrichoceras from Družetić; lateral and dorsal views. • A - Beyrichoceras jadarense sp. nov., holotype MB.C.25668.1 from sample 2009-DRZ2; × 1.5. • B - Beyrichoceras jadarense sp. nov., paratype MB.C.25686 from loose block 2010-2; $\times 1.5$. - C - Beyrichoceras jadarense sp. nov., paratype MB.C.25668.2 from sample 2009-DRZ2; $\times 1.5$. D - Beyrichoceras crenistriatoide Kullmann, 1962, specimen MB.C.25650.1 from loose block 2012-36; × 2.5. • E - Beyrichoceras crenistriatoide Kullmann, 1962, specimen MB.C.25650.2 from loose block $2012-36 ; \times 2.5$. 
beginning, there are wide-standing and slightly crenulated growth lines, which form a shallow lateral sinus and turn forward for a low and wide ventral projection, the growth lines, then become finer and densely spaced. At the end of the volution, at a conch diameter of $19 \mathrm{~mm}$, fine spiral lines develop out of stronger crenulation of the growth lines, which still extend with the lateral sinus and ventral projection.

Specimen MB.C.25650.2 has $18 \mathrm{~mm}$ conch diameter (Fig. 10E) and is generally similar to specimen MB.C.25650.1 (Fig. 10D). It is slightly stouter (ww/dm 0.75 ) and has a cuboid whorl profile.

Discussion. - According to Kullmann (in Stevanović \& Kullmann 1962), this species was found in the "lower" as well as the "upper" fauna. However, our new collections demonstrate that this species is restricted to the stratigraphically older of the assemblages, where it co-occurs with Entogonites. Specimen BEO600-551.73:592-484, which putatively comes from the "lower horizon", has a lithology that assigns it to the "upper horizon" (i.e., Entogonites tetragonus horizon).

Suture lines are usually not preserved in this material, but it can be stated that the shell ornament with the rather fine growth lines does not belong to Nuculoceras (which shows an ornament with strong riblet-like growth lines) but to Beyrichoceras. The suture line figured by Kullmann (in Stevanović \& Kullmann 1962) does not contradict an assignment to Beyrichoceras.

Kullmann (in Stevanović \& Kullmann 1962) had only small individuals up to $18 \mathrm{~mm}$ conch diameter available for study and hence was not aware of the spirally ornamented subadult and adult stage.

However, it appears to be clear that at this growth stage clear ornamental differences separate $B$. crenistriatoide from the new species $B$. jadarense. In $B$. crenistriatoide, the ornament is still dominated by growth lines extending with a ventral projection, while in $B$. jadarense sp. nov. there is already an ornament dominated by spiral lines and the growth lines are biconvex with a ventral sinus.

Superfamily Girtyocerataceae Wedekind, 1918 Family Girtyoceratidae Wedekind, 1918

\section{Genus Calygirtyoceras Korn, Klug \& Mapes, 1999}

\section{Calygirtyoceras sp.}

Figure 11

Material. - Three juvenile specimens.

Description. - Specimen MB.C.25662 (Fig. 11) has nearly $7 \mathrm{~mm}$ conch diameter and shows the characteristic juvenile conch morphology of the genus. It is thickly discoidal (ww/dm nearly 0.60 ) and subevolute (uw/dm nearly 0.40 ) with a subangular umbilical margin that separates the flattened and oblique umbilical wall and the flattened, wide venter. The ornament shows lamellar growth lines, which posses a ventral projection and are strongest on the umbilical margin.

Family Entogonitidae Ruzhencev \& Bogoslovskaya, 1971

\section{Genus Ubites Korn \& Sudar, 2010}

Type species. - Ubites filipovici Korn \& Sudar, 2010.

Diagnosis. - Entogonitidae with complex ontogeny. Inner whorls evolute, adult whorls with narrower umbilicus caused by stronger whorl overlap. Inner whorls circularly coiled. Shell ornament with sharp biconvex riblets; inner whorls with sharp dichotomizing or intercalating ribs. Ventrolateral projection of riblets low in the adult stage, ventral sinus moderately deep. Deep steinkern constrictions in the subadult and adult stage.

Included species. - filipovici: Ubites filipovici Korn \& Sudar, 2010, Serbia; pseudocyclus: Nomismoceras pseudocyclus Campbell, Brown \& Coleman, 1983, p. 97, Queensland; divnae: Ubites divnae sp. nov., Serbia; novaki: Ubites novaki sp. nov., Serbia.

Discussion. - The three species within the genus Ubites show some morphological range, particularly in the width of the umbilicus. The narrowly umbilicated Ubites novaki sp. nov. shows, in the conch proportions, close similarities to representatives of the genera Bollandites and Bollandoceras, but differs in the dichotomizing riblets.

Ubites differs from Entogonites in the regularly coiled inner whorls and in the ontogenetic development, which shows an adult stage in which the uw/dm ratio is significantly reduced.

Ubites filipovici Korn \& Sudar, 2010 Figure 12A-I

1962 Gastrioceras (Branneroceras) branneri branneri Smith. - Kullmann in Stevanović \& Kullmann, p. 86 , pl. 2, fig. 1 .

2010a Ubites filipovici Korn \& Sudar. - Korn et al., p. 362, text-fig. 6.

Holotype. - Specimen MB.C.19130.1, illustrated here in Fig. 12A. 
Type locality and horizon. - Milivojevića Kamenjar section, Družetić (NW Serbia); sample DRZ 2, Ubites filipovici horizon, Entogonites Genus Zone.

Material. - 125 specimens in the new collections and two specimens in the Natural History Museum, Belgrade; conch diameter up to $16.5 \mathrm{~mm}$.

Diagnosis. - Species of Ubites with a thinly discoidal, evolute conch $(\mathrm{ww} / \mathrm{dm}=0.35-0.45 ; \mathrm{uw} / \mathrm{dm}=0.50-0.55)$ at $8 \mathrm{~mm} \mathrm{dm}$; conch thinly discoidal, evolute $(\mathrm{ww} / \mathrm{dm}=0.40$; $\mathrm{uw} / \mathrm{dm}=0.47)$ at $16 \mathrm{~mm} \mathrm{dm}$. Aperture low $(\mathrm{WER}=$ $1.50-1.60)$ in the adult stage.

Description. - Holotype MB.C.19130.1 is an incomplete, slightly distorted specimen with $16 \mathrm{~mm}$ conch diameter; it demonstrates a rapid ontogenetic change from the evolute juvenile stage into the adult morphology (Fig. 12A). This change takes place within only one volution, in which the whorl height becomes significantly larger. At $16 \mathrm{~mm} \mathrm{dm}$, the flanks are slightly flattened and the umbilical margin is subangular. The last volution shows the excellently preserved shell ornament, consisting of sharp riblets, of which three stand within one millimetre. Every second of these riblets is intercalated near the umbilical margin; the main riblets begin on the umbilical wall and form a sharp elongate node on the umbilical margin. The riblets form a shallow sinus on the umbilical margin, a low projection in the inner flank area, a very shallow sinus on the midflank, a low ventrolateral projection, and a moderately deep ventral sinus. Parallel to the growth lines extend two shell constrictions standing approximately $120^{\circ}$ apart. They begin in the inner flank area and extend with the same depth across flanks and venter.

The smaller paratype MB.C.19130.2 (8.1 mm conch diameter) represents the juvenile growth stage, in which the conch is still evolute (uw/dm $=0.51$ ). The whorls are wide $(\mathrm{ww} / \mathrm{wh}=1.42)$ and crescent-shaped in this stage, and flanks and venter are regularly rounded. The shell ornament shows about 50 sharp riblets; between these, finer intercalatory riblets begin in the inner flank area. The riblets extend almost linearly across the inner flanks, bend forward to form a moderately high ventrolateral projection, and then turn back for a moderately deep ventral sinus (Fig. 12D).

Small specimens such as paratype MB.C.19130.4 (5.5 mm conch diameter) display similar conch morphology and shell ornament (Fig. 12C). This specimen is more widely umbilicate $(\mathrm{uw} / \mathrm{dm}=0.55)$ than the larger ones.

Discussion. - Kullmann (in Stevanović \& Kullmann 1962) had only two small specimens, and he attributed these, probably because of the dichotomising ribs, to the North American Morrowan (late Bashkirian) index species Branneroceras branneri. This determination did not consider the

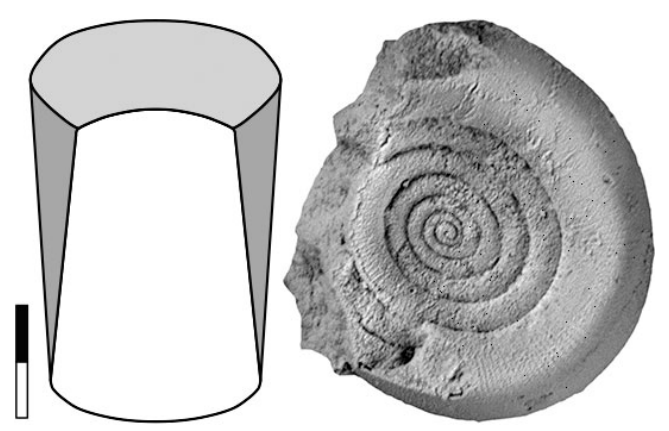

Figure 11. Calygirtyoceras sp. from Družetić; lateral and dorsal views of specimen MB.C.25662 from sample 2008-DRZ2; × 4.0 .

small size of the Serbian specimens, which only superficially resemble juveniles of $B$. branneri. The reconstruction of the suture line by Kullmann (in Stevanović \& Kullmann 1962, fig. 4a) cannot be confirmed, as the figured specimen does not show a clear suture line.

U. filipovici Korn \& Sudar is similar to U. pseudocyclus, but that species has, at $16 \mathrm{~mm}$ diameter (i.e. the same size as the holotype of $U$. filipovici), less sharp riblets with a more linear course across flanks and venter. The umbilicus is wider in $U$. pseudocyclus (uw $/ \mathrm{dm}=0.47$, in contrast to 0.42 in $U$. filipovici). U. pseudocyclus co-occurs, at the type locality Mundubbera (Queensland), with species of the genera Irinoceras, Bollandites, Maxigoniatites and Cantabricanites, which can be taken as evidence for an early Late Viséan age similar to U. filipovici.

$U$. divnae sp. nov. has, at a comparable conch diameter, a much narrower umbilicus than $U$. filipovici (at $8 \mathrm{~mm}$ conch diameter: $\mathrm{uw} / \mathrm{dm}=>0.50$ in $U$. filipovici but $<0.40$ in $U$. divnae).

\section{Ubites divnae sp. nov.}

Figure 12J-L

Holotype. - Specimen MB.C.25654.1; illustrated in Fig. 12J.

Type locality and horizon. - Milivojevića Kamenjar section, Družetić (NW Serbia); loose block 36, Entogonites tetragonus horizon, Entogonites Genus Zone.

Material. - 21 specimens; conch diameter up to $12 \mathrm{~mm}$.

Etymology. - Named after Divna Jovanović (Belgrade, Serbia) for her engagement in the field collections.

Diagnosis. - Species of Ubites with a thickly discoidal, subevolute conch $(\mathrm{ww} / \mathrm{dm}=0.50 ; \mathrm{uw} / \mathrm{dm}=0.35-0.40)$ at $8 \mathrm{~mm} \mathrm{dm}$. Aperture low $($ WER $=1.50-1.60)$ in the adult stage. 
Description. - Holotype MB.C.25654.1 (8.3 mm conch diameter; Fig. 12J) is a deformed specimen with rather well-preserved shell ornament. The conch is thickly discoidal and subevolute in this growth stage (ww/dm $\sim 0.53$; $\mathrm{uw} / \mathrm{dm} \sim 0.38$ ) with a low coiling rate (WER 1.55). It has a straight umbilical wall, a narrowly rounded umbilical margin and flanks converging to the broadly rounded venter. The shell ornament shows fine and densely spaced primary riblets, between whose secondary riblets are intercalated near the umbilicus. The riblets have a biconvex course with equally low dorsolateral and ventrolateral projections, a very shallow lateral sinus and a shallow ventral sinus. Two shell constrictions arranged in $90^{\circ}$ distance follow the course of the growth lines.

Paratype MB.C.25667.1 is an incomplete specimen with $7 \mathrm{~mm}$ conch diameter (Fig. 12K); it is thickly discoidal and subevolute $(\mathrm{ww} / \mathrm{dm}=0.50 ; \mathrm{uw} / \mathrm{dm}=0.38)$ and closely resembles the holotype.

Discussion. - Ubites divnae sp. nov. closely resembles $U$. filipovici in the shell ornament with biconvex riblets dichotomizing near the umbilicus, but the conch shape offers clear characters for a separation. $U$. divnae differs from $U$. filipovici in the narrower umbilicus (uw/dm $>0.50$ at $8 \mathrm{~mm} \mathrm{dm}$ in $U$. filipovici but $<0.40$ in $U$. divnae).

A similar species is $U$. novaki sp. nov., but this species has a narrower umbilicus (uw/dm $\sim 0.30$ at $8 \mathrm{~mm} \mathrm{dm}$ ) than $U$. divnae (uw/dm $\sim 0.40$ at $8 \mathrm{~mm} \mathrm{dm}$ ).

\section{Ubites novaki sp. nov.}

Figure 12M-O

1962 Cravenoceras cowlingense Bisat. - Kullmann in Stevanović \& Kullmann, p. 78, pl. 1, fig. 3.

Holotype. - Specimen MB.C.25639.1; illustrated in Fig. 12M.

Type locality and horizon. - Milivojevića Kamenjar section, Družetić (NW Serbia); float block, Entogonites tetragonus horizon, Entogonites Genus Zone.

Material. - 13 newly collected specimens and three speci- mens in the Natural History Museum, Belgrade; conch diameter up to $13 \mathrm{~mm}$.

Etymology. - Named after Matevž Novak (Ljubljana, Slovenia) for his engagement in the field collections.

Diagnosis. - Species of Ubites with a thickly discoidal to thinly pachyconic, subinvolute conch (ww/dm 0.60; $\mathrm{uw} / \mathrm{dm} \sim 0.30)$ at $8 \mathrm{~mm} \mathrm{dm}$. Aperture low (WER 1.65) in the adult stage.

Description. - Holotype MB.C.25639.1 is a weakly deformed specimen with nearly $10 \mathrm{~mm}$ conch diameter (Fig. 12M). It is thickly discoidal (ww/dm nearly 0.60) and subinvolute (uw/dm nearly 0.30 ); it possesses a steep umbilical wall, a narrowly rounded umbilical margin and a weakly depressed whorl cross-section (ww/wh nearly 1.50) with a broadly rounded venter. The shell ornament shows coarse growth lines, which sometimes are strengthened like fine riblets. They extend with a weakly biconvex course with low projections and shallow sinuses across flanks and venter. The shell has also constrictions arranged in angles of $90^{\circ}$; they follow the course of the growth lines and are deepest in the midflank area.

Paratype MB.C.25639.2 shows the morphology of the smaller stage. It is $6.5 \mathrm{~mm}$ in diameter and covered with shell material (Fig. 12O). It has an umbilicus of about a third of the conch diameter and a broadly rounded venter. The growth lines are coarse like riblets; they extend with low dorsolateral and ventrolateral projections across the flank and form a ventral sinus that is slightly deeper than the lateral sinus. Deep shell constrictions are arranged in angles of $90^{\circ}$.

The smaller paratype MB.C.25618.1 has, at $6 \mathrm{~mm}$ conch diameter, conch proportions similar to the holotype (Fig. 12N). It shows the well-preserved shell ornament with rather coarse, riblet-like growth lines, extending with a very low dorsolateral projection, a very shallow lateral sinus, a low ventrolateral projection and a rather narrow and shallow ventral sinus. Riblets are intercalated in the inner flank area. The last volution possesses eight short constrictions on the flank; these constrictions lead to the impression that the areas between them are raised like broad and rounded nodes.

Figure 12. Representatives of the genus Ubites from Družetić; lateral and dorsal views; all $\times 4$. • A-I - Ubites filipovici Korn \& Sudar, 2010; A - holotype MB.C.19130 from sample 2008-DRZ2; B - paratype MB.C.19130.5 from sample 2008-DRZ2; C-paratype MB.C.19130.3 from sample 2008-DRZ2; D - paratype MB.C.19130.2 from sample 2008-DRZ2; E - paratype MB.C.19129.1 from sample 2008-DRZ1; F - paratype MB.C.19130.7 from sample 2008-DRZ2; G - specimen MB.C.25633 from loose block 2010-3; H - specimen MB.C.25676.1 from sample 2009-DRZ2; I - specimen MB.C.25676.2 from sample 2009-DRZ2. • J-L - Ubites divnae sp. nov.; J - holotype MB.C.25654.1 from loose block 2012-36; K - paratype MB.C.25667.1 from sample 2008-DRZ2; L - paratype MB.C.25638 from block 2010-DRZ1. • M-O - Ubites novaki sp. nov.; M - holotype MB.C.25639.1 from block 2010-DRZ1; N - paratype MB.C.25618.1 from sample 2009-DRZ1; O - paratype MB.C.25639.2 from block 2010-DRZ1. 
Dieter Korn \& Milan N. Sudar • The Late Devonian and Early Carboniferous ammonoids from NW Serbia
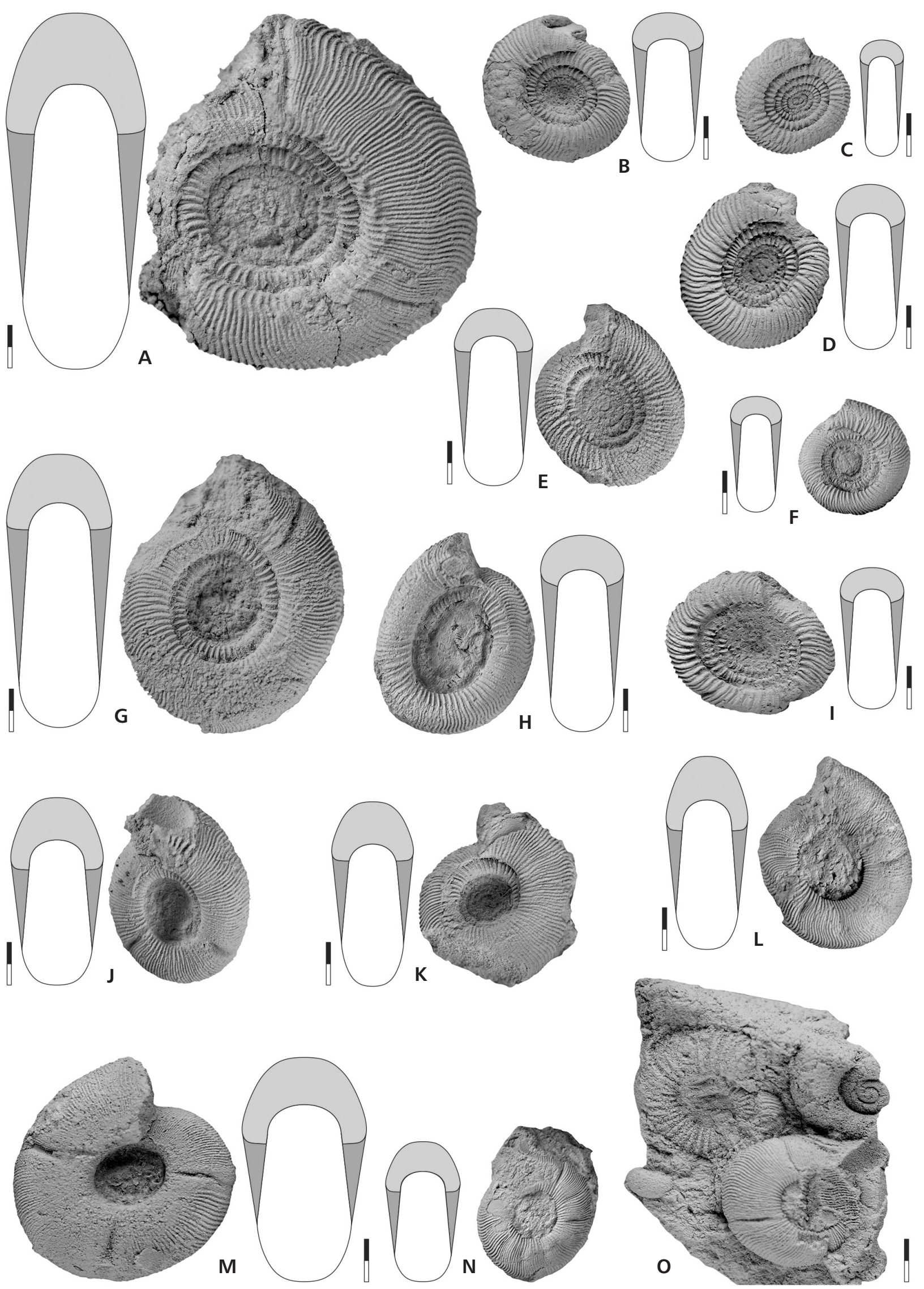
Discussion. - The specimen figured by Kullmann (in Stevanović \& Kullmann 1962, pl. 1, fig. 3) cannot, on the basis of conch shape and ornament, be assigned to the genus Cravenoceras. All characters plus the stratigraphical occurrence speak for identification of the specimen as an $U b i$ tes species, which together with similar species co-occurs with Entogonites.

Ubites novaki sp. nov. has similarities with $U$. divnae; both species resemble each other in the course of the growth lines and in the conch proportions, but $B$. novaki has a narrower umbilicus (uw/dm $\sim 0.30$ at $8 \mathrm{~mm} \mathrm{dm}$ ) than $U$. divnae (uw/dm $\sim 0.40$ at $8 \mathrm{~mm} \mathrm{dm}$ ).

There are also some similarities to representatives of the genera Bollandites and Bollandoceras. Bollandites rileyi Korn \& Tilsley for instance has similar conch morphology.

\section{Genus Entogonites Kittl, 1904}

Type species. - Tetragonites Grimmeri Kittl, 1904 (by monotypy).

Diagnosis. - Entogonitidae with simple ontogeny. Adult whorls slightly narrower umbilicate; inner whorls tetrangularly coiled.

Included species. - borealis: Entogonites borealis Gordon, 1957, p. 53; Alaska; grimmeri: Tetragonites Grimmeri Kittl, 1904, p. 677, Bosnia and Herzegovina; nasutus: Pericyclus nasutus Schmidt, 1941, p. 151, Harz; saharensis: Entogonites saharensis Korn, Klug \& Mapes, 2005, p. 363, Anti-Atlas; tetragonus: Gastrioceras (Branneroceratoides) tetragonum Kullmann, 1962, p. 88, Serbia; serbicus: Entogonites serbicus sp. nov., Serbia; burbankensis: Entogonites burbankensis Korn \& Titus, 2011, p. 131, Utah; acus: Entogonites acus Korn \& Titus, 2011, p. 134, Utah.

\section{Entogonites grimmeri (Kittl, 1904)}

Figure 13A-H

1904a Tetragonites Grimmeri nov. gen. n. f.; Kittl, p. 677, pl. 21, figs 18-24.

1958 Nomismoceras grimmeri (Kittl). - Kostić-Podgorska, p. 28, pl. 15, figs 1-4.

1962 Gastrioceras (Branneroceratoides) tetragonum Kullmann sp. nov. - Kullmann in Stevanović \& Kullmann, p. 88, pl. 2, figs 5, 6 (only).

1963 Entogonites grimmeri (Kittl). - Nicolaus, p. 135, pl. 3, fig. 14, pl. 7, figs 2-4.

1988 Entogonites grimmeri (Kittl). - Korn, p. 47, pl. 5, figs 1-4 (see for more synonymy).
1990 Entogonites grimmeri (Kittl). - Korn, p. 26, pl. 4, figs $1-4$.

Material. - 46 specimens in the new collection and five specimens in the Natural History Museum, Belgrade.

Description. - Specimen MB.C.25620.1 is about $8 \mathrm{~mm}$ in conch diameter and represents the growth stage, in which the tetrangular coiling is transformed into regular coiling (Fig. 13B). The specimen is thinly discoidal $(\mathrm{ww} / \mathrm{dm}=$ $0.38)$ and evolute (uw/dm $=0.49$ ) with a depressed whorl profile $(\mathrm{ww} / \mathrm{wh}=1.48)$. The ornament shows almost 40 sharp primary ribs on the last volution; they are straight on the flank and turn forward to a rather high ventrolateral projection. On the venter they run with a sharp, chevron-shaped sinus. The ribs bifurcate in the outer flank area, but in some places intercalatory ribs can also be seen.

Of the smaller specimens, it is particularly MB.C.25747 (Fig. 13D) that deserves attention. It has a diameter of $6 \mathrm{~mm}$ and is laterally deformed. The conch is thinly discoidal $(\mathrm{ww} / \mathrm{dm}=0.39)$ and subevolute $(\mathrm{uw} / \mathrm{dm}=$ 0.42). The coiling is strikingly tetrangular with a square-shaped umbilicus. The last volution has about 35 sharp ribs, which dichotomize on the outer flank.

Discussion. - Entogonites grimmeri has originally been described from flattened material collected in the vicinity of Prača near Sarajevo (Bosnia and Herzegovina) by Kittl (1904a, b), a locality only 110 km southwest from Družetić. The morphology of the specimens suggests that the species occurs at both places.

Among the Entogonites species from Družetić, E. grimmeri has the strongest tetrangular coiling and the sharpest ribs with the highest ventrolateral projection.

\section{Entogonites serbicus sp. nov.}

Figure 13I-K

Holotype. - Specimen MB.C.25597, illustrated in Fig. 13I.

Type locality and horizon. - Milivojevića Kamenjar section, Družetić (NW Serbia); float block, Entogonites tetragonus horizon, Entogonites Genus Zone.

Material. - 8 specimens up to $16 \mathrm{~mm}$ conch diameter.

Etymology. - Named after the country of Serbia.

Diagnosis. - Species of Entogonites with a thinly discoidal conch $(\mathrm{ww} / \mathrm{dm}=0.35-0.40)$, moderately wide umbilicus (uw/dm $=0.35-0.40)$ and broadly rounded venter at $8 \mathrm{~mm}$ conch diameter. Aperture moderately low (WER = 1.80-1.90). Inner whorls with very weak tetrangular coiling. 

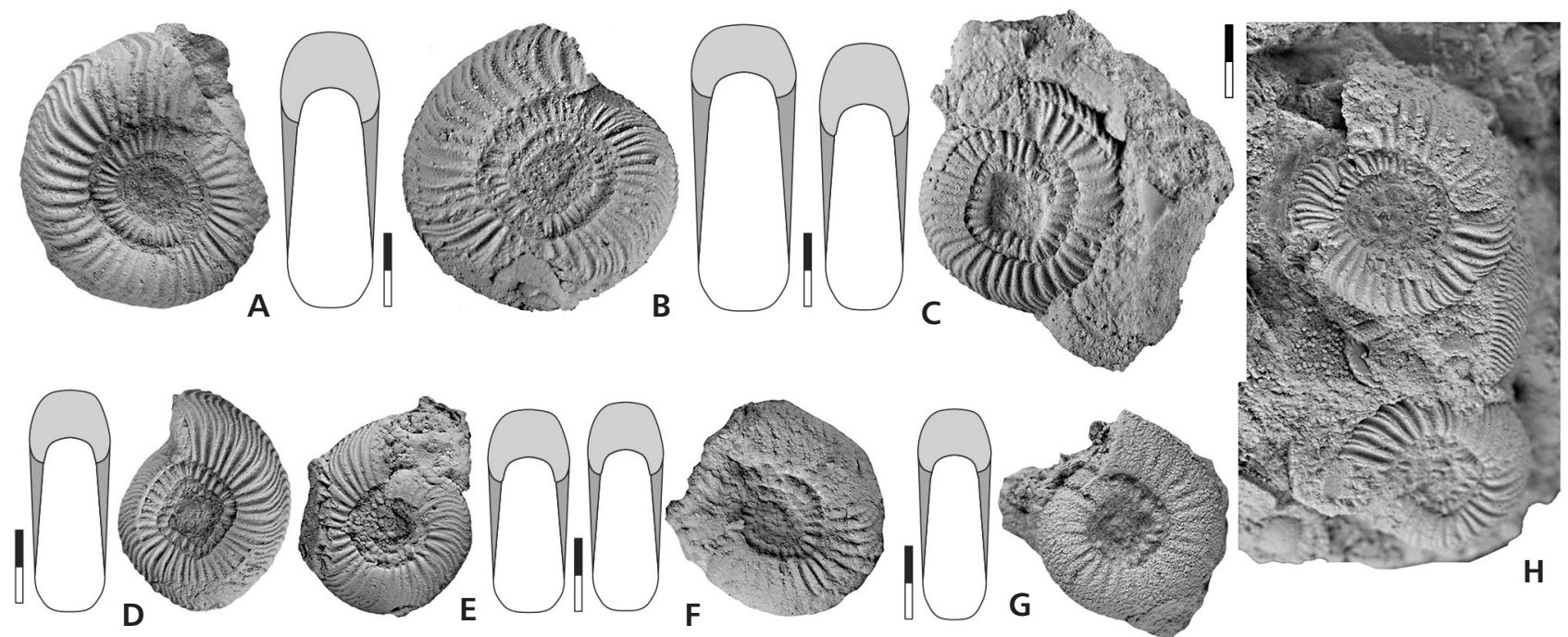

$\mathrm{H}$
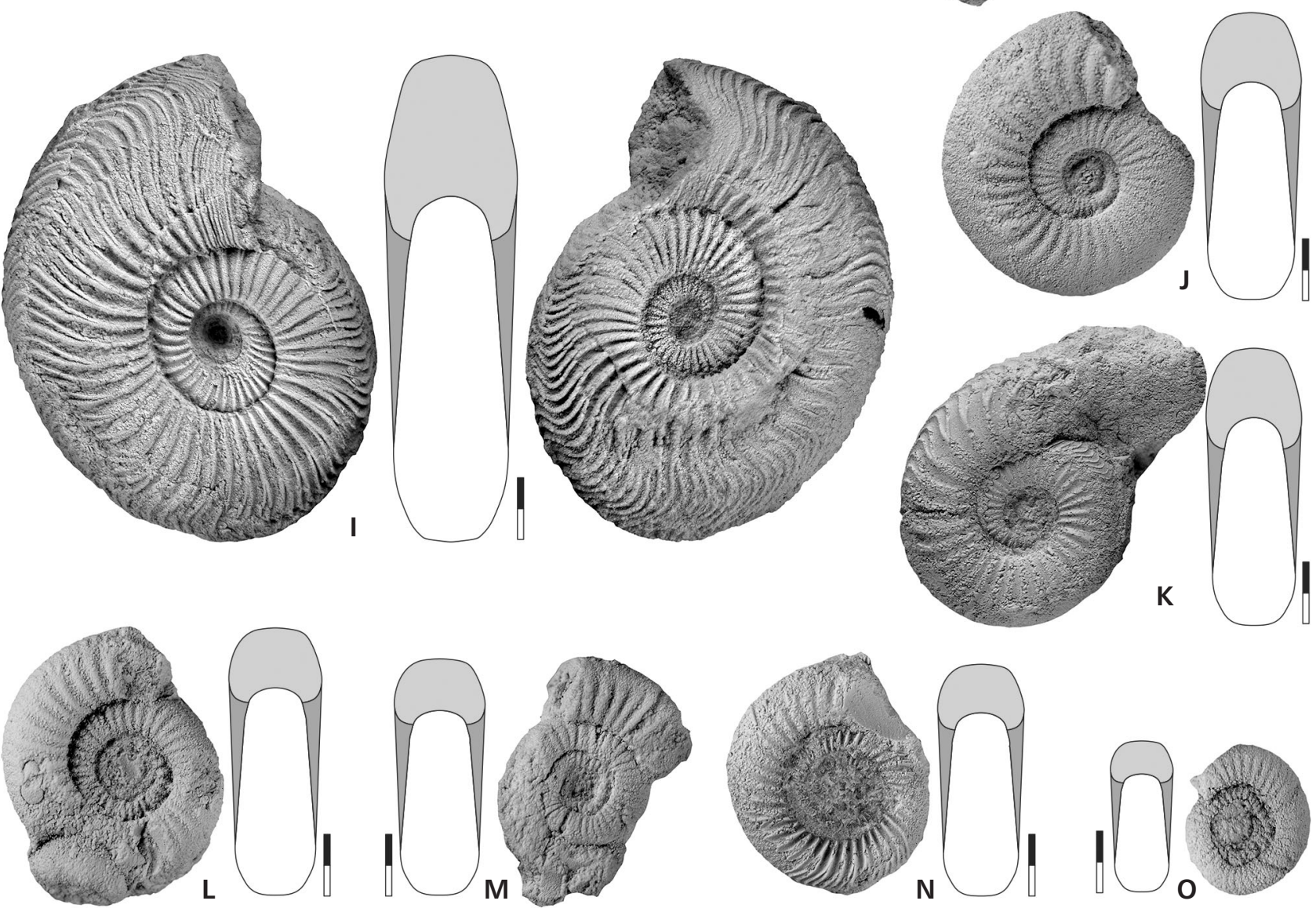

Figure 13. Representatives of the genus Entogonites from Družetić, lateral and dorsal views; all $\times 4$. • A-H - Entogonites grimmeri (Kittl, 1904); A - specimen MB.C.25599.1 from sample 2008-DRZ1; B - specimen MB.C.25620.1 from sample 2009-DRZ1; C - specimen MB.C.25620.2 from sample 2009-DRZ1; D - specimen MB.C.25599.2 from sample 2008-DRZ1; E - specimen MB.C.25599.3 from sample 2008-DRZ1; F - specimen MB.C.25599.4 from sample 2008-DRZ1; G - specimen MB.C.25599.5 from sample 2008-DRZ1; H - specimen MB.C.25596 from float. - I-K - Entogonites serbicus sp. nov.; I - holotype MB.C.25597 from float; J - paratype MB.C.25600 from sample 2008-DRZ1; K - paratype MB.C.25635 from loose block 2010-DRZ1. • L-O - Entogonites tetragonus (Kullmann, 1962); L - specimen MB.C.18128.1 from sample 2008-DRZ1; M - specimen MB.C.19128.2 from sample 2008-DRZ1; N - specimen MB.C.25636 from block 2010-DRZ1; O - specimen MB.C.19128.5 from sample 2008-DRZ1. 
Shell ornament with 30 rounded and ventrolaterally dichotomising ribs. Ventrolateral projection of ribs low, ventral sinus shallow.

Description. - Holotype MB.C.25597 is the largest available specimen with $16 \mathrm{~mm}$ conch diameter and shows the adult conch morphology and ornament (Fig. 13I). The conch is extremely discoidal $(\mathrm{ww} / \mathrm{dm}=0.27)$ and subevolute (uw/dm $=0.32$ ) with a whorl expansion rate of 2.00. The umbilical margin is rounded; the flanks stand subparallel and are delimited by a subangular ventrolateral margin from the rounded venter. The ornament changes during the last growth interval. In the largest growth stage (which is only visible in a short growth interval), it consists of sharp dense riblets. The last well-preserved half volution shows 25 sharp ribs on the flank. They have a protracted direction on the flank and dichotomize in the middle of the flank, from here they continue as slightly weaker ribs, which form a pronounced ventrolateral projection and turn back to a chevron-shaped ventral sinus. Another half volution earlier, 20 sharp ribs can be counted. In this stage, the ribs are straight on the flank.

Paratype MB.C.25600.1 is a fairly well-preserved steinkern specimen with $9 \mathrm{~mm}$ conch diameter (Fig. 13J). It is thinly discoidal (ww/dm $=0.38$ ) and subinvolute (uw/dm $=0.39$ ). During the last half volution, the umbilicus opens and the uw/dm ratio increases from 0.35 to 0.39 . The umbilical margin is rounded and the flanks converge towards the broadly rounded venter that is limited from the flanks by a weakly angular shoulder. About 30 rounded riblets are present on the last volution; these riblets show a very shallow lateral sinus and bend forward toward a low ventrolateral projection. The ribs become much weaker in the ventrolateral area, where they bifurcate into weaker branches.

Paratype MB.C.25635 has almost the same conch proportions (Fig. 13K). It has slightly sharper ribs than the holotype.

Discussion. - Entogonites serbicus sp. nov. belongs to the species of the genus with a relatively narrow umbilicus. Similarly involute are E. burbankensis (which possesses strongly tetrangular inner whorls) and E. nasutus (with very low ventrolateral projection of the ribs). Of the Serbian species, E. serbicus is the one with the least tetrangular coiling of the inner whorls.

\section{Entogonites tetragonus (Kullmann, 1962)} Figures 13L-O

1962 Gastrioceras (Branneroceratoides) tetragonum Kullmann sp. nov.; Kullmann in Stevanović \& Kullmann, p. 88, pl. 2, figs 2-4 (only).

1971 Entogonites tetragonus (Kullmann). - Ruzhencev \& Bogoslovskaya, p. 37. 2010a Entogonites tetragonus (Kullmann). - Korn et al., p. 361 , text-fig. 5 .

Holotype. - Specimen BEO600-551.73:592-476 (Natural History Museum Belgrade), illustrated by Stevanović \& Kullmann (1962, pl. 2, fig. 2).

Type locality and horizon. - Milivojevića Kamenjar site in Družetić (NW Serbia); "upper horizon" of Stevanović \& Kullmann (1962), Entogonites Genus Zone.

Material. - The holotype and about 20 paratypes in the Natural History Museum Belgrade (some of which are poorly preserved) and additionally 157 newly collected specimens; conch diameter up to $9.5 \mathrm{~mm}$.

Diagnosis. - Species of Entogonites with a thinly discoidal conch $(\mathrm{ww} / \mathrm{dm}=0.35-0.40)$, wide umbilicus $(\mathrm{uw} / \mathrm{dm}=$ $0.45-0.50)$ and slightly flattened venter at $8 \mathrm{~mm}$ conch diameter. Aperture moderately high (WER = 1.80-1.90). Inner whorls with moderate tetrangular coiling. Shell ornament with 35 moderately strong, rounded and ventrolaterally dichotomising ribs per volution. Ventrolateral projection of ribs low, ventral sinus moderately deep.

Description. - Holotype BEO600-551.73:592-476 (Kullmann in Stevanović \& Kullmann 1962, pl. 2, fig. 2) is a relatively well-preserved specimen with nearly $9 \mathrm{~mm}$ conch diameter. It is extremely discoidal ( $\mathrm{ww} / \mathrm{dm}=0.34$ ) and evolute $(\mathrm{uw} / \mathrm{dm}=0.46)$. The specimen has about 35 rounded ribs on the last volution. They have a straight radial course on the flank and in the ventrolateral area turn forward to form a rather low projection and a shallow ventral sinus.

Specimen MB.C.19128.1 is a rather well preserved specimen with $8.5 \mathrm{~mm}$ conch diameter (Fig. 13L). It is thinly discoidal and evolute $(\mathrm{ww} / \mathrm{dm}=0.36$; $\mathrm{uw} / \mathrm{dm}=$ 0.46) and possesses a moderately high aperture (WER = 1.83). The inner whorls show inconspicuous tetrangular coiling. About 30 rounded ribs can be counted on the last volution; they extend in a linear course across the inner flank and bifurcate on the outer flank. The apertural branch forms a rather high ventrolateral projection and a shallow sinus on the venter.

The other, smaller specimens are similar in conch shape and ornament. Some of them, such as specimen MB.C.19128.2 (7 mm dm; Fig. 13M) and MB.C.19128.5 (4.2 mm dm; Fig. 13O) possess constrictions extending parallel to the riblets. The tetrangularly coiled stage ends at about $6 \mathrm{~mm}$ conch diameter.

Discussion. - E. tetragonus is the type species of the subgenus Gastrioceras (Branneroceratoides) Kullmann, 1962, which was erroneously regarded as a Namurian genus by 


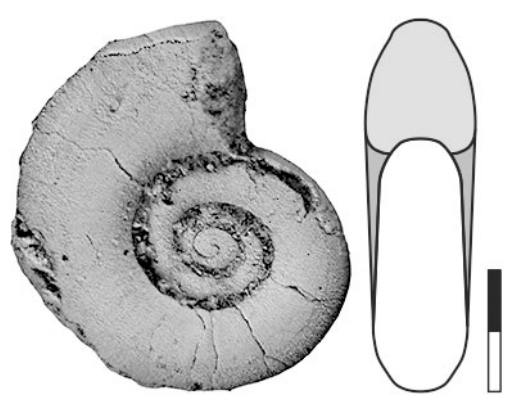

Figure 14. Nomismoceras sp. from Družetić; lateral and dorsal views of specimen MB.C.25666 from sample 2008-DRZ2; × 4.

Kullmann (in Stevanović \& Kullmann 1962). The figured, strongly fragmentary suture line with a putatively acute adventive lobe and a parallel-sided external lobe (Kullmann in Stevanović \& Kullmann 1962, text-fig. 4b, unfortunately no specimen number was given) is obviously incorrect in these respects; it is clear that the subgenus has to be put in synonymy with Entogonites.

Not all of the specimens listed by Kullmann (in Stevanović \& Kullmann 1962) do in fact belong to this species; two of the figured ones (figs 5 and 6 of pl. 2) show a narrower umbilicus and a more pronounced projection of the ribs; they must be regarded as E. grimmeri.

E. tetragonus differs from E. grimmeri in the less developed tetrangular coiling of the inner whorls. The riblets in E. tetragonus are less sharp when compared with E. grimmeri. E. nasutus also has weakly tetrangular inner whorls, but in this species the umbilicus is much narrower (uw/dm $=0.35)$ than in E. tetragonus (uw/dm $=0.45)$. $E$. borealis has a narrower umbilicate conch than $E$. tetragonus, and E. saharensis possesses sharper ribs with higher ventrolateral projections.

Superfamily Nomismocerataceae Librovitch, 1957 Family Nomismoceratidae Librovitch, 1957

\section{Genus Nomismoceras Hyatt, 1884}

\section{Nomismoceras sp.}

Figure 14

Material. - Six specimens up to $6 \mathrm{~mm}$ conch diameter.

Description. - Specimen MB.C.25666 (Fig. 14) is, with $6 \mathrm{~mm}$ conch diameter, the largest of the available specimens. It is extremely discoidal $(\mathrm{ww} / \mathrm{dm}=0.30)$ and subevolute (uw/dm $=0.40$ ) with a low whorl embracing rate and a high aperture $(\mathrm{WER}=2.20)$. The whorl profile shows, on the last half volution, a rounded umbilical wall; the whorls are widest in the inner flank area and show a wide and shallow spiral groove on the outer flank and a broadly rounded

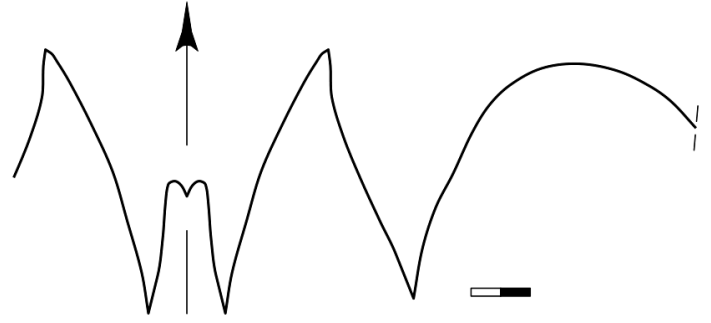

Figure 15. Hypergoniatites sp.; suture line of specimen MB.C.25741 from Družetić; loose block 2012-29, at $17 \mathrm{~mm}$ wh; $\times 3.0$.

venter. The shell ornament shows very delicate growth lines, which extend with a dorsolateral projection and a deep lateral sinus across the flank.

Superfamily Goniatitaceae Hyatt, 1884

Family Goniatitidae Hyatt, 1884

\section{Genus Hypergoniatites Ruzhencev \& Bogoslovskaya, 1970}

\section{Hypergoniatites sp.}

Figure 15

Material. - Only one fragmentary specimen.

Description. - The single fragment MB.C.25741 is poorly preserved. At a whorl height of about $17 \mathrm{~mm}$, it shows a suture line with a very narrow, V-shaped E lobe, an acute ventrolateral saddle and a slightly asymmetric A lobe (Fig. 15). While there is no doubt about the genus attribution, an assignment to a distinct species is impossible.

Family Delepinoceratidae Ruzhencev, 1957

Subfamily Dombaritinae Kullmann, 2007

Genus Dombarites Librovitch, 1957

\section{Dombarites falcatoides Ruzhencev \& Bogoslovskaya,} 1970

Figure 16A, B, D, F, G

1962 Proshumardites (Trigonoshumardites) wocklumerioides Kullmann subgen. nov. et sp. nov.; Kullmann in Stevanović \& Kullmann, p. 98, pl. 4, figs 1, 2 (only).

1970 Dombarites falcatoides sp. nov. - Ruzhencev \& Bogoslovskaya, p. 60, pl. 8, figs 1-3.

1971 Dombarites falcatoides Ruzhencev \& Bogoslovskaya. - Ruzhencev \& Bogoslovskaya, p. 224, pl. 15, figs 1-5. 
Material. - 17 specimens ranging in their diameters from $5 \mathrm{~mm}$ to $80 \mathrm{~mm}$ from new collections. Many of the specimens are rather poorly preserved and species attribution of some of the material may not be completely clear. There are at least two specimens in the Natural History Museum, Belgrade.

Description. - Specimen MB.C.25733 is a fragment of a large specimen of about $80 \mathrm{~mm}$ conch diameter (Fig. 16A). Although incompletely preserved it is obvious that the conch was rather stout (ww/dm $\sim 0.60$ ). It shows a poorly preserved shell ornament, which possesses about 45 rather coarse spiral lines (umbilicus to midventer) as well as rhythmically strengthened growth lines producing a conspicuous falcate ornament. At the largest diameter, a shallow shell constriction is visible.

MB.C.25745 is a specimen of about $48 \mathrm{~mm}$ conch diameter. It has a strongly deformed body chamber but a less deformed phragmocone (Fig. 16B). The conch shape is, at about $35 \mathrm{~mm} \mathrm{dm}$, thickly pachyconic (ww/dm 0.75). The ornament of the specimen shows spiral lines nearly as wide as their interspaces.

Specimen S4 is a well-preserved, rounded-triangularly coiled individual of $12.5 \mathrm{~mm}$ conch diameter (Kullmann in Stevanović \& Kullmann 1962, pl. 4, fig. 1). It is thickly pachyconic (ww/dm $\sim 0.80$ ) with a very narrow umbilicus (uw/dm 0.10). The shell ornament shows about 80 spirals and growth lines as strong as spirals; the growth lines extend with a rather deep lateral sinus and a wide ventral projection. Three shell constrictions are deepest on the flanks. The suture line is not visible.

The smallest available specimen MB.C.25690.1 is thickly globular $(\mathrm{ww} / \mathrm{dm}=1.07)$ with a nearly closed umbilicus (Fig. 16G). The specimen shows triangular coiling caused by three deep constrictions arranged $120^{\circ}$ apart. The shell ornament shows dominant biconvex growth lines (with a very shallow ventral sinus) and finer spiral lines.

Discussion. - The material of Dombarites from the South Urals (Ruzhencev \& Bogoslovskaya 1971) is much better preserved than the material from Družetić, and hence a comparison is rather difficult. It is obvious that some of the specimens attributed by Kullmann (in Stevanović \& Kullmann 1962) to "Proshumardites (Trigonoshumardites) wocklumerioides" do in fact belong to Dombarites.

\section{Dombarites liratus Ruzhencev \& Bogoslovskaya, 1971} Figures 16C, E, 17

1962 Proshumardites (Trigonoshumardites) wocklumerioides Kullmann nov. subgen. et nov. sp.; Kullmann in Stevanović \& Kullmann, p. 98, pl. 3, fig. 3 (only).
1971 Dombarites liratus sp. nov.; Ruzhencev \& Bogoslovskaya, p. 232, pl. 18, figs 1-5.

Material. - Six specimens ranging in their diameters from $28 \mathrm{~mm}$ to $70 \mathrm{~mm}$ from new collections; preservation of the specimens is moderately good. There is at least one specimen in the Natural History Museum, Belgrade.

Description. - Specimen BEO600-551.73:592-471 is a slightly distorted specimen with $38 \mathrm{~mm}$ conch diameter. The conch is pachyconic (ww/dm $\sim 0.70$ ) with a narrow umbilicus (uw/dm $\sim 0.10$ ). The specimen shows few shell remains with about 80-90 fine spirals being separated by wider interspaces. The suture line is well visible; it has a $\mathrm{V}$-shaped $\mathrm{E}$ lobe and a median saddle of more than half the height of the external lobe depth. The ventrolateral saddle is acute; the flanks of the adventive lobe are inflexed with angular and very short secondary lobes.

Specimen MB.C.25731.1 is a comparatively well preserved, only slightly deformed individual of $26 \mathrm{~mm}$ diameter displaying the ornament of the recrystallized shell (Fig. 16C). The conch is thinly pachyconic and involute $(\mathrm{ww} / \mathrm{dm}=0.67$; $\mathrm{uw} / \mathrm{dm}=0.13$ ) with broadly rounded venter. A total of 40 spiral lines can be counted from the umbilicus to the midventer; their width equals the width of their interspaces. Three barely visible shell constrictions standing about 90 degrees apart are visible in the midflank area. The suture line shows a V-shaped E lobe with a median saddle as high as half of the E lobe depth and very narrow, $\mathrm{V}$-shaped prongs. The ventrolateral saddle is acute and the A lobe is slightly asymmetric with a weak inflexion of the ventral flank (Fig. 17B).

Specimen MB.C.25697 is the fragment of a specimen with maximally $30 \mathrm{~mm}$ conch diameter; it is very similar to specimen MB.C.25731.1. Parts of an inner volution are visible; this possesses finer spiral lines than the outer whorl (Fig. 16E).

Discussion. - Preservation of the material is sufficient for an attribution to D. liratus, as the falcatoid ornament typical for the otherwise similar species D. parafalcatoides is absent. The main difference to the co-occurring $D$. falcatoides is the slender conch.

\section{Genus Proshumardites Rauser-Tschernoussowa, 1928}

\section{Proshumardites uralicus Librovitch, 1941}

Figure 18

1941 Proshumardites uralicus sp. nov.; Librovitch, p. 153, pl. 40, fig. 9, text-fig. 43.

1962 Proshumardites (Proshumardites) serbicus Kullmann nov. spec.; Kullmann in Stevanović \& Kullmann, p. 96, pl. 3, fig. 1, text-fig. 6a. 

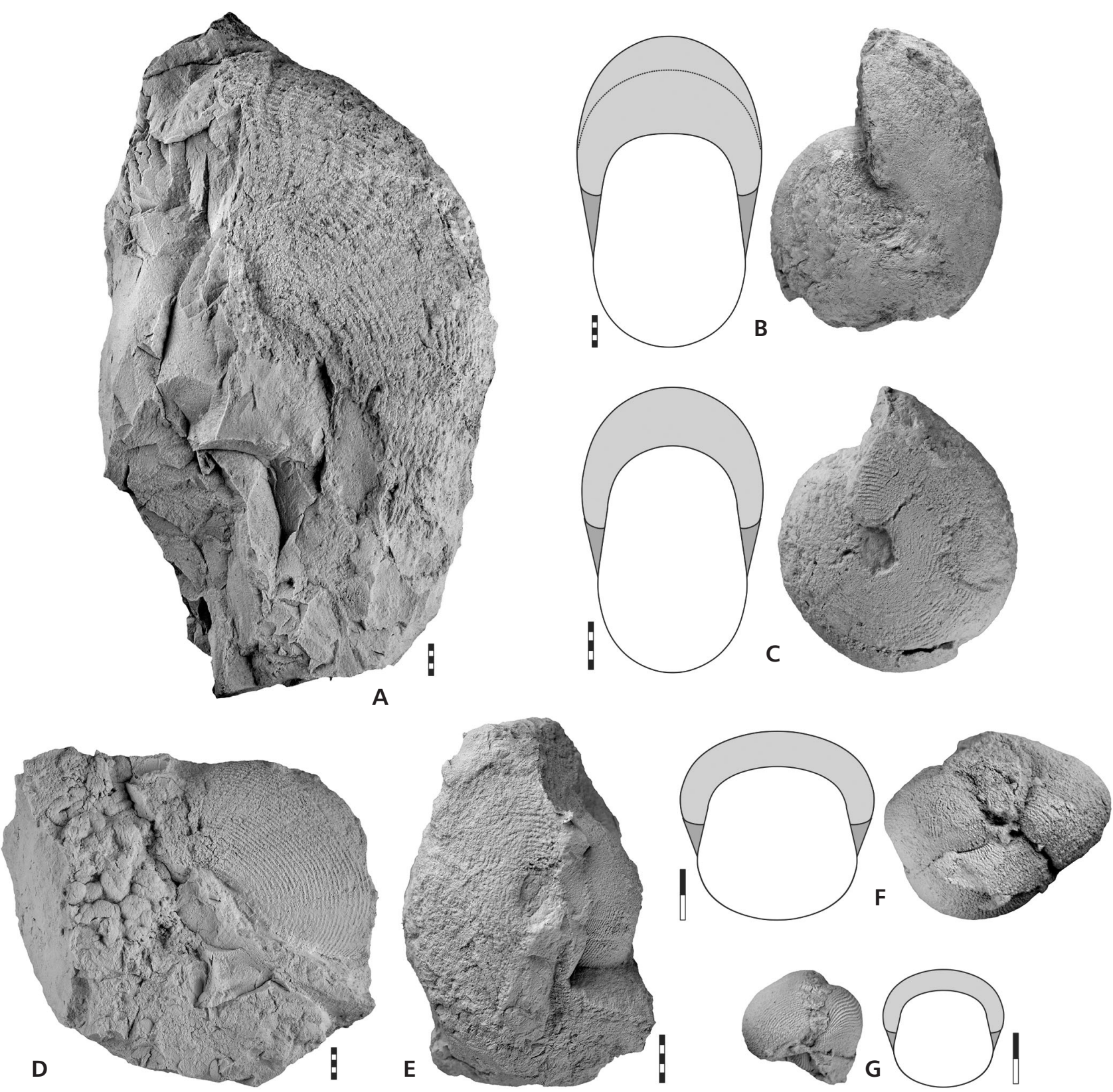

Figure 16. Representatives of the genus Dombarites from Družetić; lateral and dorsal views. - A - Dombarites falcatoides Ruzhencev \& Bogoslovskaya, 1970, specimen MB.C.25733 from loose block 2012-17; × 1. • B - Dombarites falcatoides Ruzhencev \& Bogoslovskaya, 1970, specimen MB.C.25745 from float; $\times 1$ (the dotted line refers to the probable original outline before tectonic deformation). - C - Dombarites liratus Ruzhencev \& Bogoslovskaya, 1971, specimen MB.C.25731.1 from loose block 2012-16; × 1.5. • D - Dombarites falcatoides Ruzhencev \& Bogoslovskaya, 1970, specimen MB.C.25738.1 from loose block 2012-24; × 1. E - Dombarites liratus Ruzhencev \& Bogoslovskaya, 1971, specimen MB.C.25697 from sample 2009-C; × 1.5. • F - Dombarites falcatoides Ruzhencev \& Bogoslovskaya, 1970, specimen MB.C.25711.1 from loose block 2011-1; × 4. • G - Dombarites falcatoides Ruzhencev \& Bogoslovskaya, 1970, specimen MB.C.25690.1 from loose block 2011-1; × 4 .

1962 Proshumardites (Trigonoshumardites) wocklumerioides Kullmann subgen. nov. et sp. nov.; Kullmann in Stevanović \& Kullmann, p. 98, pl. 3, figs 2, 4, 5, text-fig. $6 \mathrm{~b}$ (only).

1971 Pericleites uralicus Librovitch. - Ruzhencev \& Bogoslovskaya, p. 37, 237, pl. 20, figs 1-4.
Material. - One fragment from new collections. A suite of about 20 specimens (of which some are poorly preserved) is stored in the collections of the Natural History Museum, Belgrade.

Description. - The holotype of "Proshumardites (Proshu- 


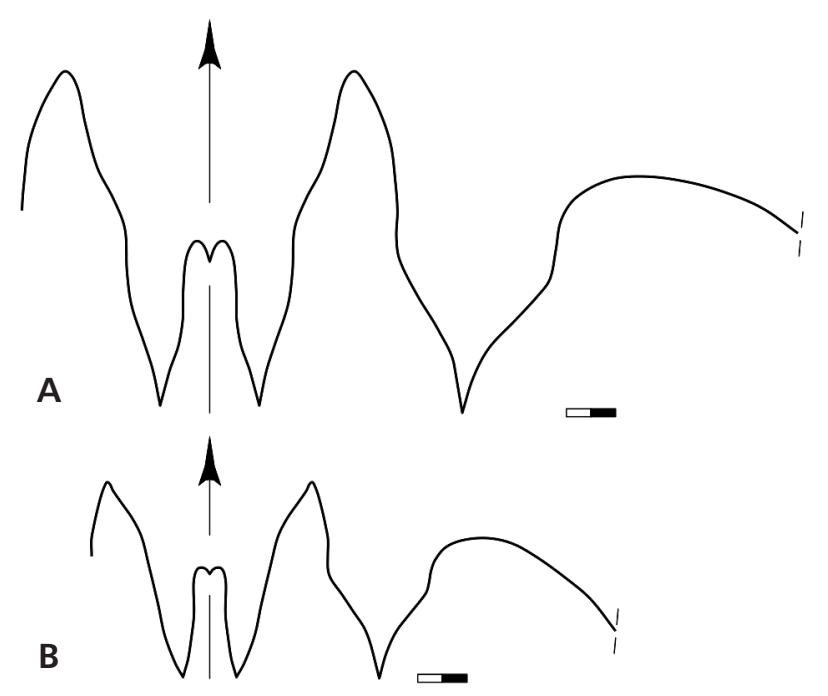

Figure 17. Suture lines of Dombarites liratus Ruzhencev \& Bogoslovskaya, 1971 from Družetić. • A - specimen in the Natural History Museum, Belgrade, at $20 \mathrm{~mm}$ wh. $\bullet \mathrm{B}$ - specimen MB.C.25731.1 from loose block 2012-16, at $26.0 \mathrm{~mm} \mathrm{dm}, 17.8 \mathrm{~mm} w w, 13.6 \mathrm{~mm}$ wh.

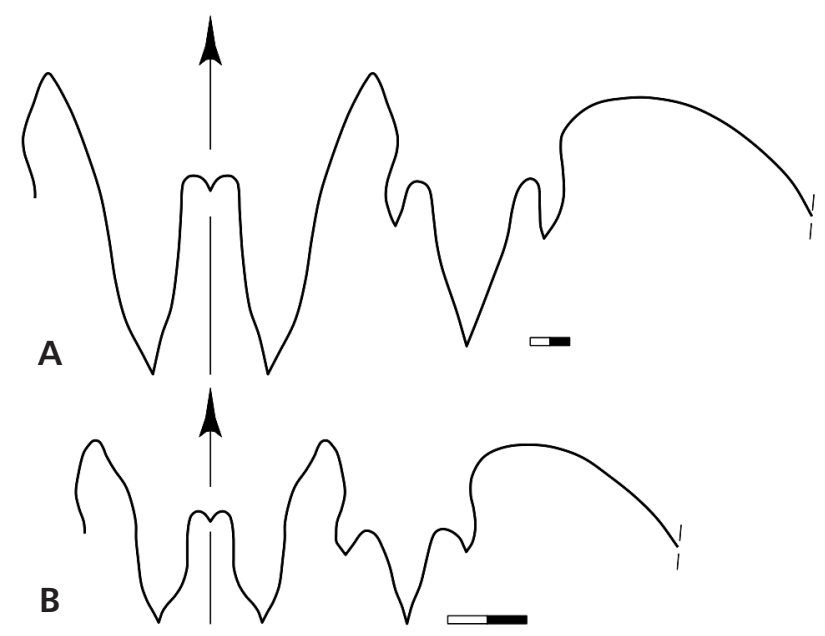

Figure 18. Suture lines of Proshumardites uralicus Librovitch, 1941 from Družetić. • A - specimen BEO600-551.73:592-444 [holotype of "Proshumardites (Proshumardites) serbicus Kullmann, 1962"], at 43-48 mm dm; × 2.0. • B - specimen S16 [holotype of "Proshumardites (Trigonoshumardites) wocklumerioides Kullmann, 1962"], at about $14 \mathrm{~mm} \mathrm{ww} ; \times 4.0$.

mardites) serbicus Kullmann, 1962", specimen S1, is an individual with about $55 \mathrm{~mm}$ conch diameter and it was preparated with a strong acid treatment. It is embedded in dark grey dense limestone without iron stains. The conch is, at $48 \mathrm{~mm}$ conch diameter, thinly pachyconic (ww/dm $0.65)$ with a very narrow umbilicus (uw/dm $\sim 0.13$ ) and a weakly depressed whorl profile (ww/wh $\sim 1.25$ ). Few shell remains are preserved with wide-standing, fine lamellar growth lines that show a rursiradiate course on the flank. The external suture line is visible in parts and can be ob- tained from two positions at 43 and $48 \mathrm{~mm}$ conch diameter. The external lobe has nearly straight flanks and narrow $\mathrm{V}$-shaped prongs; the height of the median saddle is not clear but it is possibly more than $60 \%$ of the E lobe depth. The ventrolateral saddle is barely visible in the specimen but obviously not completely acute. On the flank follows the adventive lobe, which is trifurcate with a large primary prong and small claw-shaped secondary prongs (Fig. 18A).

The holotype of "Proshumardites (Trigonoshumardites) wocklumerioides Kullmann, 1962”, specimen BEO600-551.73:592-445, is a specimen also embedded in dark grey dense limestone without iron stains; shell remains are preserved on one side and the other side was etched for preparation of the suture line. At a conch diameter of $21.7 \mathrm{~mm}$, the conch is thinly pachyconic (ww/dm = 0.73 ) and the umbilicus is nearly closed (uw/dm $=0.06$ ). The whorl profile is horseshoe-shaped with broadly rounded venter and a low aperture (WER $=1.54)$. The shell ornament shows 80 fine spirals (from umbilicus to umbilicus) with interspaces about five times wider than the lines; the growth lines are very fine. The suture line is visible at a conch width of about $14 \mathrm{~mm}$. It shows a Y-shaped E lobe with weakly asymmetric lanceolate prongs and a median saddle slightly higher than the E lobe depth. The ventrolateral saddle is very narrow and subacute and the A lobe is trifurcated with a larger $\mathrm{V}$-shaped primary prong and two asymmetric, claw-shaped secondary prongs (Fig. 18B).

Discussion. - Ruzhencev \& Bogoslovskaya (1971) regarded the two Serbian species as synonyms of $P$. uralicus. These authors did not see any difference between $P$. uralicus and $P$. wocklumerioides and argued that the development of the ornament (i.e., losing the spiral lines at a diameter of about $35 \mathrm{~mm}$ ) and also the conch dimensions speak for a synonymy of the three species.

It is questionable if all specimens regarded by Kullmann (in Stevanović \& Kullmann 1962) as "Proshumardites (Trigonoshumardites) wocklumerioides" really belong to Proshumardites. Doubts can be raised particularly for the specimens BEO600-551.73:592-471 (Kullmann in Stevanović \& Kullmann 1962, pl. 3, fig. 3), which has a Dombarites-like A lobe and S4 (pl. 4, fig. 1), which shows a reticulate shell ornament with equally strong growth lines and spiral lines. Furthermore, the small triangularly coiled specimens are very unlikely to belong to $P$. uralicus; most probably they are the juvenile individuals of Dombarites falcatoides.

Family Delepinoceratidae Ruzhencev, 1957

Genus Platygoniatites Ruzhencev, 1956 

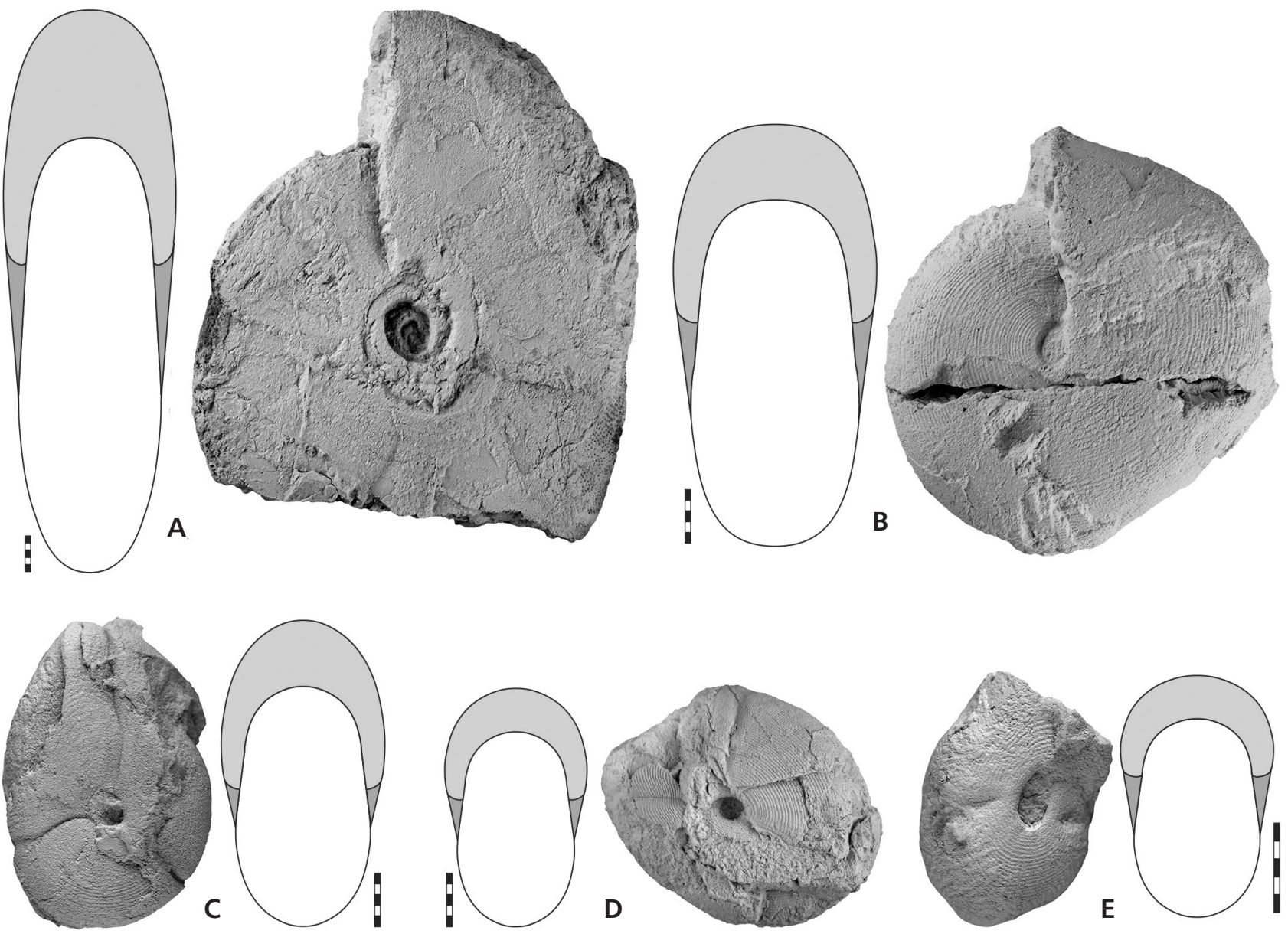

Figure 19. Representatives of the genus Platygoniatites from Družetić; lateral and dorsal views. • A - Platygoniatites molaris Ruzhencev, 1958, specimen MB.C.25742 from loose block 2012-30; × 1. • B - Platygoniatites omniliratus Ruzhencev \& Bogoslovskaya, 1971, specimen MB.C.25730 from loose block 2012-13; × 1.5. • C - Platygoniatites omniliratus Ruzhencev \& Bogoslovskaya, 1971, specimen MB.C.25749.1 from float; $\times 1.5$. - D - Platygoniatites omniliratus Ruzhencev \& Bogoslovskaya, 1971, specimen MB.C.25692.1 from sample 2009-C; $\times 1.5$. • E - Platygoniatites omniliratus Ruzhencev \& Bogoslovskaya, 1971, specimen MB.C.25749.2 from float; × 2.5.

\section{Platygoniatites molaris Ruzhencev, 1956}

Figures 19A, 20A

1956 Platygoniatites molaris sp. nov.; Ruzhencev, p. 158, text-figs $1-3$.

1971 Platygoniatites molaris Ruzhencev. - Ruzhencev \& Bogoslovskaya, p. 217, pl. 12, figs 2, 3, pl. 13, figs 2-4.

Material. - Five strongly deformed specimens between 40 and $75 \mathrm{~mm}$ conch diameter.

Description. - MB.C.25742 (Fig. 19A) is a partly crushed and deformed specimen of about $75 \mathrm{~mm}$ conch diameter with a very narrow umbilicus (uw/dm $\sim 0.14$ ). Shell ornament is barely visible except for fine spiral lines on the outer flank; the flanks of the steinkern are smooth. Poorly preserved wrinkle layer structures can be seen on the outer flank.

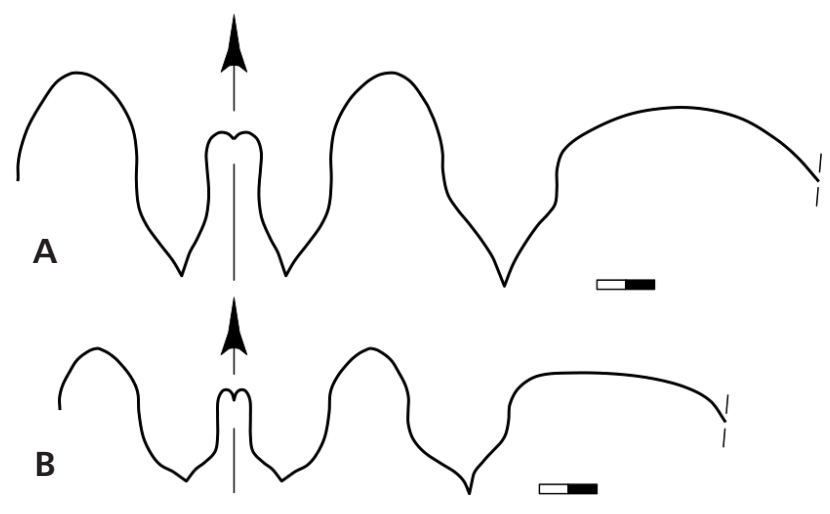

Figure 20. Suture lines of Platygoniatites from Družetić; all $\times 2.5$. - A - Platygoniatites molaris Ruzhencev, 1958, specimen MB.C.25748 from float, at $17.2 \mathrm{~mm}$ ww, $17.5 \mathrm{~mm}$ wh. $\bullet \mathrm{B}$ - Platygoniatites omniliratus Ruzhencev \& Bogoslovskaya, 1971, specimen MB.C.25730 from loose block 2012-13, at $14.7 \mathrm{~mm}$ ww, $14.2 \mathrm{~mm}$ wh. 

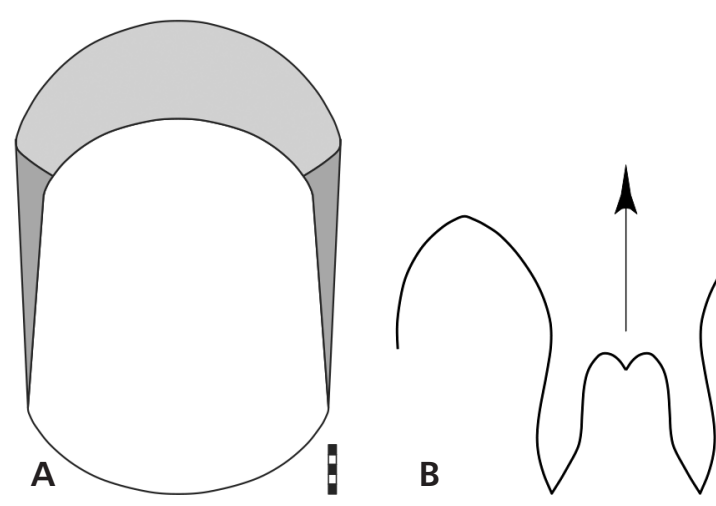

Specimen MB.C.25748 is a fragment of a strongly deformed specimen with about $50 \mathrm{~mm}$ conch diameter. At a diameter of $30 \mathrm{~mm}$, the conch is thickly discoidal and involute (ww/dm $\sim 0.50 ; \mathrm{uw} / \mathrm{dm} \sim 0.07$ ) with a broadly rounded venter. In this stage the suture line possesses a very wide external lobe with slightly asymmetric lanceolate prongs, a narrowly rounded ventrolateral saddle, and a slightly asymmetric adventive lobe with inflexed flanks (Fig. 20A).

Specimen MB.C.25716 is a somewhat crushed specimen with nearly $40 \mathrm{~mm}$ conch diameter. The inner whorl ( $24 \mathrm{~mm} \mathrm{dm}$ ) shows fine spiral lines on the flank, but on the outer whorl $(\sim 36 \mathrm{~mm} \mathrm{dm})$ the spirals appear to be restricted to the venter.

\section{Platygoniatites omniliratus Ruzhencev \& Bogoslovskaya, 1971}

Figures 19B-E, 20B

1971 Platygoniatites omniliratus sp. nov.; Ruzhencev \& Bogoslovskaya, p. 216, pl. 11, figs 1-5, pl. 12, fig. 1, pl. 13, fig. 1.

Material. - Six moderately well preserved specimens between 10 and $40 \mathrm{~mm}$ conch diameter.

Description. - Specimen MB.C. 25730 is a rather well preserved specimen with $40 \mathrm{~mm}$ diameter (Fig. 19B). The conch is thickly discoidal (ww/dm $\sim 0.50$ ) and involute (uw/dm $=0.08$ ) with subparallel flanks and a continuously rounded venter. Large parts of the specimen are covered with shell material, which shows 50 sharp spiral lines from the umbilicus to the midventer. These spirals are half as wide as their interspaces and possess a fine granulation where they are crossed by the sharp growth lines. The growth lines are biconvex with low lateral projections (of which the dorsolateral projection is higher than the ventrolateral) and a rather deep ventral sinus. The suture line (Fig. 20B) of the same specimen shows a very wide E lobe with wide, weakly asymmetric prongs and a very narrow median saddle that reaches more than half the height of the
Figure 21. Syngastrioceras europaeum Kullmann, 1962 from Družetić ("lower horizon"); dorsal view and suture line of holotype BEO600-551.73:592-455. • A dorsal view; $\times 1.0$. $\bullet \mathrm{B}$ - suture line, at $45 \mathrm{~mm} \mathrm{dm} ; \times 2.0$.
E lobe depth. The ventrolateral saddle is nearly symmetric tectiform with parallel flanks in the middle part. The adventive lobe is weakly asymmetric and more strongly curved on the ventral side.

Specimens MB.C.25749 (Fig. 19C) and MB.C.25692.1 (Fig. 19D) are deformed individuals with nearly $27 \mathrm{~mm}$ and $24 \mathrm{~mm}$ diameter, respectively. Their approximated conch proportions are: $\mathrm{ww} / \mathrm{dm} \sim 0.58, \mathrm{uw} / \mathrm{dm} \sim 0.08$. Both show the shell ornament similar to specimen MB.C. 25730 with biconvex, sharp growth lines and stronger, granulated spirals. The shell has an ornament with about 45 sharp spiral lines (umbilicus to midventer) and three prominent shell constrictions about $120^{\circ}$ apart.

The small specimen MB.C.25749.2 is a juvenile, deformed specimen of $9 \mathrm{~mm}$ conch diameter (Fig. 19E); the estimated conch proportions are: ww/dm $\sim 0.85$, uw/dm 0.14 . It is covered with shell. About 40 fine spiral lines can be counted from the umbilical margin to the midventer, they are narrower than the interspaces. Three well-visible shell constrictions appear in a short distance from the umbilical margin, they are most prominent in the midflank area. The outer flank is occupied by a wrinkle structure.

Remarks. - The material from Družetić shows the same conch proportions as the Uralian material and the conch ornament does not show significant differences. Despite the comparatively poor preservation of the Serbian material, a specific identification can be stated quite confidently.

Superfamily Somoholitaceae Ruzhencev, 1938

Family Glaphyritidae Ruzhencev \& Bogoslovskaya, 1971

\section{Genus Syngastrioceras Librovitch, 1938}

\section{Syngastrioceras europaeum (Kullmann, 1962)}

Figure 21

1962 Eoasianites (Eoasianites) europaeus Kullmann sp. nov.; Kullmann in Stevanović \& Kullmann, p. 92, pl. 2 , figs 7,8 . 
1971 Glaphyrites europaeus (Kullmann). - Ruzhencev \& Bogoslovskaya, p. 37.

Holotype. - Specimen BEO600-551.73:592-455 (Stevanović Coll.; Natural History Museum Belgrade); illustrated by Stevanović \& Kullmann (1962, pl. 2, fig. 8).

Type locality and horizon. - Milivojevića Kamenjar site in Družetić (NW Serbia); "lower horizon" of Stevanović \& Kullmann (1962), probably Fayettevillea-Delepinoceras Genus Zone.

Material. - Five specimens in the Natural History Museum Belgrade. New material has not been discovered.

Description. - Holotype BEO600-551.73:592-455 from Kullmann (in Stevanović \& Kullmann 1962, pl. 2, fig. 8) is a rather poorly preserved fragment embedded in dark grey dense limestone. It is, at $48 \mathrm{~mm}$ conch diameter, thinly pachyconic (ww/dm 0.67) with a wide umbilicus (uw/dm 0.52) and a strongly depressed whorl profile (ww/wh $\sim 2.90)$. The umbilical margin is narrowly rounded and the broad venter is broadly rounded (Fig. 21A). Shell remains are not visible; one steinkern constriction turns forward to form a broad ventral projection. The suture line has a pouched external lobe with narrow lanceolate prongs, the ventrolateral saddle is weakly angular and the adventive lobe is widely lanceolate with flanks nearly parallel in the upper part (Fig. 21B).

Paratype BEO600-551.73:592-456 (Kullmann in Stevanović \& Kullmann 1962, pl. 2, fig. 7) is a deformed steinkern specimen of about $28 \mathrm{~mm}$ conch diameter. The specimen suffered from rough preparation, and hence the conch dimensions cannot be obtained precisely. It appears that the conch is wider than in the holotype but the umbilicus is narrower. One steinkern constriction is visible, running strongly prorsiradiate across the flank and forming a narrow, high ventral projection. The suture line is visible, showing a pouched adventive lobe.

Discussion. - Kullmann (in Stevanović \& Kullmann 1962, p. 94) described a specimen of only $4 \mathrm{~mm}$ diameter as "Eoasianites (Eoasianites) europaeus?". This specimen comes from the "upper horizon" (Entogonites Genus Zone); it belongs in the genus Bollandites, but specific attribution is impossible.

Ruzhencev \& Bogoslovskaya (1971, p. 37) regarded the species as an early representative in the evolution of the genus Glaphyrites. However, the shapes of the external lobe and the ventrolateral saddle speak for an attribution to the genus Syngastrioceras.

Superfamily Neoglyphiocerataceae Plummer \& Scott, 1937 Family Cravenoceratidae Ruzhencev, 1957

Subfamily Cravenoceratinae Ruzhencev, 1957

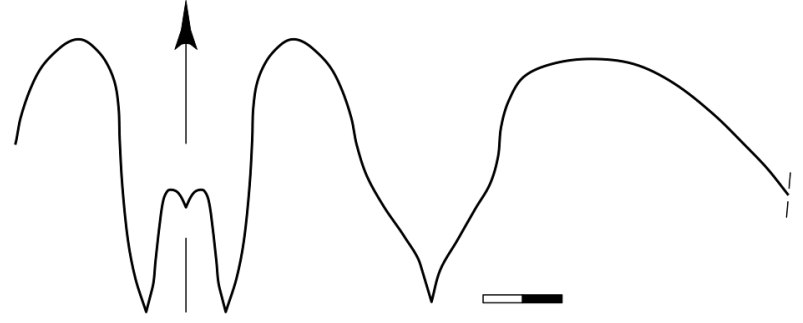

Figure 22. Cravenoceras sp.; suture line of specimen MB.C.25720 from Družetić; float, at $\sim 13 \mathrm{~mm}$ wh.

\section{Genus Cravenoceras Bisat, 1928}

\section{Cravenoceras sp.}

Figure 22

Material. - One fragmentary specimen.

Description. - The single specimen MB.C.25720 is poorly preserved with a conch diameter of about $30 \mathrm{~mm}$. It can only be said that the conch is thickly discoidal with a slightly opened umbilicus. The suture line allows attribution to the genus Cravenoceras; it shows a narrow V-shaped E lobe with slightly sinuous flanks, a rounded, weakly tectiform ventrolateral saddle and a nearly symmetric A lobe with curved flanks (Fig. 22).

Subfamily Lyrogoniatitinae Ruzhencev \& Bogoslovskaya, 1971

\section{Genus Lyrogoniatites Miller \& Furnish, 1940}

Lyrogoniatites tener Ruzhencev \& Bogoslovskaya, 1971 Figure 23A

1971 Lyrogoniatites tener sp. nov.; Ruzhencev \& Bogoslovskaya, p. 277, pl. 29, figs $1-4$.

Material. - Two specimens, 6 and $25 \mathrm{~mm}$ in diameter.

Description. - Specimen MB.C.25699.1 is an incomplete and only slightly deformed, fairly well preserved specimen with $24 \mathrm{~mm} \mathrm{dm}$ (Fig. 23A). The conch is thinly pachyconic (ww/dm 0.65) and subevolute (uw/dm 0.30); the umbilical wall is steep and flat, the umbilical margin is subangular, flanks and venter are broadly rounded. The shell ornament shows spiral lines as the most important elements; there are 20 of such spirals between the umbilical margin and the midventer. They are crossed by much finer growth lines, which extend almost linearly across the flanks and slightly turn forward to form a very low, wide ventral projection. The shell surface shows three constrictions, which follow the growth lines in their course. After the last of 

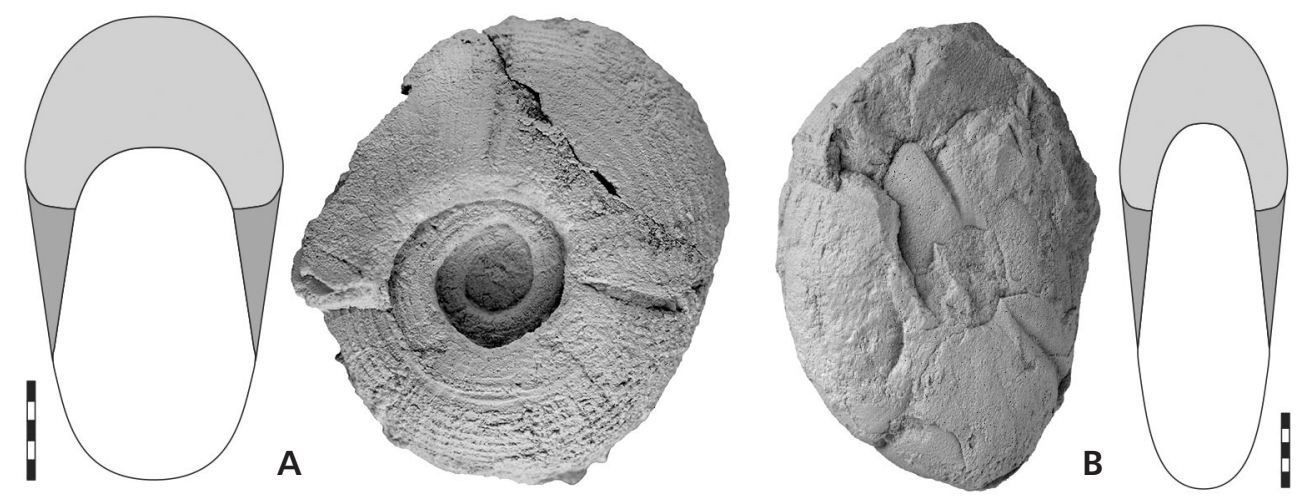

Figure 23. Representatives of the subfamily Lyrogoniatitinae from Družetić; lateral and dorsal views. • A - Lyrogoniatites tener Ruzhencev \& Bogoslovskaya, 1971; specimen MB.C.25699.1 from sample 2009-C; × 2. • B - Tympanoceras sp.; specimen MB.C.25751 from float; × 1.5.

these constrictions, the shell ornament changes in the way that spirals are lacking; instead the growth lines become slightly coarser.

\section{Genus Tympanoceras Ruzhencev, 1958}

\section{Tympanoceras sp.}

Figure 23B

Material. - One deformed specimen.

Description. - Specimen MB.C.25751 (Fig. 23B) is strongly deformed and the conch proportions can only be estimated. The conch appears to be rather slender (ww/dm $\sim 0.45)$ and subinvolute (uw/dm $\sim 0.25)$. Three constrictions can be seen on one volution; they extend radially and form a shallow ventral projection.

Family Neoglyphioceratidae Plummer \& Scott, 1937

\section{Genus Neoglyphioceras Brüning, 1923}

\section{Neoglyphioceras baccans Ruzhencev \& Bogoslovskaya, 1971}

Figure 24A

1971 Neoglyphioceras baccans sp. nov.; Ruzhencev \& Bogoslovskaya, p. 313, pl. 35, figs 2-4.

Material. - 26 specimens; diameters ranging from $4 \mathrm{~mm}$ to $17 \mathrm{~mm}$.

Description. - MB.C.25723.1 is a laterally deformed specimen with $17 \mathrm{~mm}$ diameter; the conch is thinly pachyconic and subevolute (ww/dm $\sim 0.65$; uw/dm $\sim 0.33$ ) with broadly rounded venter and steep umbilical wall. The en- tire specimen is covered by strongly recrystallized shell material. 20 coarse spiral lines are present between the umbilical wall and the midventer; they are as wide as their interspaces. One weak and slightly protracting shell constriction is visible on the midflank (Fig. 24A).

\section{Neoglyphioceras litvinovichae Ruzhencev \& Bogoslovskaya, 1971 \\ Figure 24B}

1971 Neoglyphioceras litvinovichae sp. nov.; Ruzhencev \& Bogoslovskaya, p. 317, pl. 36, figs 1-3.

Material. - Only one specimen.

Description. - MB.C.25736 is a fragment of a laterally distorted and crushed specimen of $20 \mathrm{~mm}$ diameter; the conch is thinly discoidal (ww/dm $\sim 0.40$ ) and involute (uw/dm $\sim 0.09$ ) with nearly parallel flanks and a narrowly rounded venter. A small area shows the shell ornament, this possesses 40 fine spiral lines from the umbilical margin to the midventer. The spiral lines show nearly identical distances and are slightly narrower than their interspaces. Fine biconvex growth lines cross the spiral lines; their course parallels a shell constriction, which is most prominent on the inner flank. The steinkern is smooth but shows a biconvex constriction, which is more prominent than the shell constriction and visible on flank and venter. The two constrictions show a distance of approximately $90^{\circ}$ (Fig. 24B).

\section{Neoglyphioceras sp.}

Figure 24C

Material. - Five poorly preserved specimens between 6 and $10 \mathrm{~mm}$ conch diameter. 

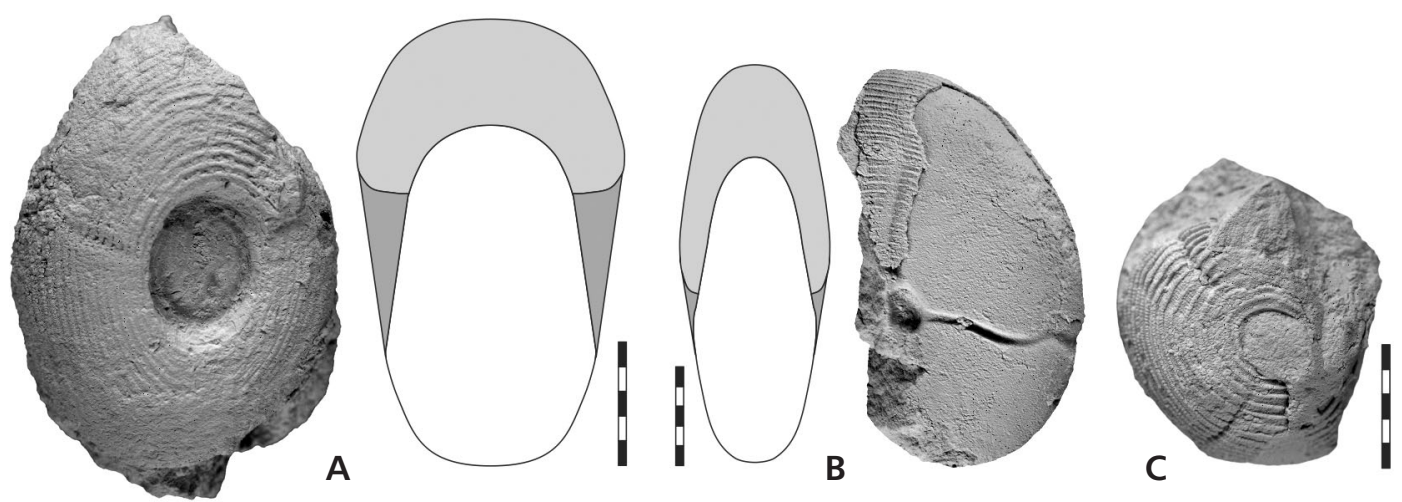

Figure 24. Representatives of Neoglyphioceras from Družetić; lateral and dorsal views. • A - Neoglyphioceras baccans Ruzhencev \& Bogoslovskaya, 1971; specimen MB.C.25723.1 from float; × 2.5. • B - Neoglyphioceras litvinovichae Ruzhencev \& Bogoslovskaya, 1971; specimen MB.C.25736 from loose block 2012-20; × 2 . C - Neoglyphioceras sp.; specimen MB.C.25701 from sample 2009-C; $\times 2.5$.

Description. - Specimen MB.C.25701 (Fig. 24C) has $10 \mathrm{~mm}$ diameter and is thickly discoidal $(\mathrm{ww} / \mathrm{dm}=0.55)$ with a narrow umbilicus (uw/dm $=0.13$ ). It possesses sharp spiral lines (30 from umbilicus to umbilicus), which are crossed by much finer growth lines. These turn slightly forward on the flank to form a moderately high ventrolateral projection and a very shallow ventral sinus.

\section{Genus Lusitanites Ruzhencev \& Bogoslovskaya, 1971}

\section{Lusitanites concavus Ruzhencev \& Bogoslovskaya, 1971}

Figure 25

1971 Lusitanites concavus sp. nov.; Ruzhencev \& Bogoslovskaya, p. 325, pl. 37, figs 5, 6 .

Material. - Four specimens which range between 11 and $23 \mathrm{~mm}$ conch diameter.

Description. - MB.C.25713.1 is a fragmentary specimen of $22.5 \mathrm{~mm}$ diameter, which on one side is entirely covered with strongly recrystallized shell material. The last whorl is deformed, but the conch proportions at $20 \mathrm{~mm}$ diameter can be estimated as follows: ww/dm $\sim 0.40$, uw/dm $\sim 0.10$. The shell ornament shows 18 sharp spiral lines from the umbilical margin to the midventer; these spirals are about half as wide as their interspaces. The shell surface and the steinkern do not show constrictions (Fig. 25A).

The smaller specimen MB.C.25717 has a $12 \mathrm{~mm}$ conch diameter and is only slightly deformed (Fig. 25B). It is thinly discoidal (ww/dm $\sim 0.42$ ) with a very narrow umbilicus (uw/dm 0.15) and a very low aperture (WER 1.50). The shell ornaments shows about 20 rounded spiral lines (umbilicus to midventer) and finer growth lines. One curved constriction can be seen on the flank.
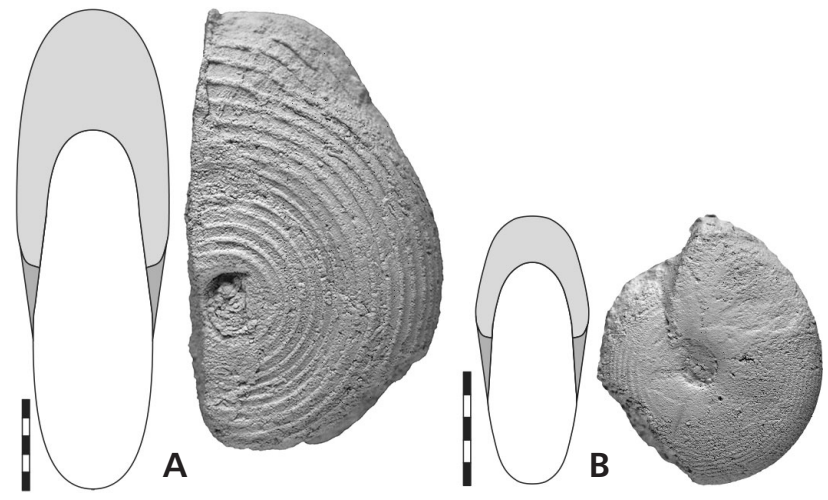

Figure 25. Lusitanites concavus Ruzhencev \& Bogoslovskaya, 1971 from Družetić; lateral and dorsal views. • A - specimen MB.C.25713.1 from loose block 2011-1; × 2. • B - Specimen MB.C.25717 from float (foot of the rock); $\times 2.5$

Family Rhymmoceratidae Ruzhencev \& Bogoslovskaya, 1971

\section{Genus Ophilyroceras Ruzhencev \& Bogoslovskaya, 1971}

Ophilyroceras tersum Ruzhencev \& Bogoslovskaya, 1971 Figure 26A-C

1971 Ophilyroceras tersum sp. nov.; Ruzhencev \& Bogoslovskaya, p. 336, pl. 38, figs 11-13.

Material. - Four moderately well preserved but fragmentary specimens between 15 and $24 \mathrm{~mm}$ conch diameter.

Description. - Specimen MB.C.25702.1 is a strongly deformed conch with about $24 \mathrm{~mm}$ diameter (Fig. 26A). It is extremely discoidal and subevolute ( $\mathrm{uw} / \mathrm{dm} \sim 0.40$ ) with a laterally compressed whorl profile. The shell ornament consists of coarse spiral lines, which are a little wider than their interspaces. From umbilicus to midventer, about 24 spirals can be counted. The steinkern is 
smooth except for barely visible impressions of the spiral lines and a forward-bending constriction, which forms a moderately high ventrolateral projection and a shallow ventral sinus.

The smaller specimens MB.C.25702.2 ( $12 \mathrm{~mm} \mathrm{dm}$; Fig. 26B) and MB.C.25732 ( $15 \mathrm{~mm} \mathrm{dm}$; Fig. 26C) differ from the preceding specimen in the presence of distinct shell constrictions. At this stage, the whorl profile is depressed or circular.

\section{Genus Rhymmoceras Ruzhencev, 1958}

\section{Rhymmoceras gracilentum Ruzhencev, 1958 Figure 26D}

1958 Rhymmoceras gracilentum sp. nov.; Ruzhencev, p. 294, text-figs 1e-z, 2e.

1962 Rhymmoceras gracilentum Ruzhencev. - Kullmann in Stevanović \& Kullmann, p. 75, pl. 1, fig. 2, text-fig. $3 \mathrm{a}$.

1971 Rhymmoceras gracilentum Ruzhencev. - Ruzhencev \& Bogoslovskaya, p. 340, pl. 40, figs 1-3.

Material. - One specimen from new collections and three specimens in the Natural History Museum, Belgrade.

Description. - Specimen BEO600-551.73:592-486 (Kullmann in Stevanović \& Kullmann 1962, pl. 1, fig. 2) is a deformed specimen of about $20 \mathrm{~mm}$ conch diameter; it is extremely discoidal (ww/dm $\sim 0.30$ ) and widely umbilicate (uw/dm $\sim 0.55$ ) with a rounded, slightly depressed whorl profile $(\mathrm{ww} / \mathrm{wh} \sim 1.15)$ and a moderately low coiling rate $(\mathrm{WER} \sim 1.75)$. The specimen shows a coarse reticulate shell ornament consisting of spiral lines (about 30 from umbilicus to umbilicus) and coarse, riblet-like growth lines (which extend with a forward direction on the flank and a very shallow ventral sinus) with approximately equal strength. Several constrictions are visible on the shell; they are accompanied by a bulge on the apical side. The steinkern shows only radial riblets.

The smaller specimen MB.C.25752 (Fig. 26D) has, at a diameter of $16 \mathrm{~mm}$, very similar conch dimensions. It is fully covered with shell showing the reticulate ornament with protracting riblet-like growth lines and coarse spiral lines.

Superfamily and family uncertain

\section{Druzeticia gen. nov.}

Type species. - Druzeticia decens gen. et sp. nov.
Derivation of name. - Named after Družetić, the village where the section Milivojevića Kamenjar is located.

Diagnosis. - Small ammonoids with thickly discoidal to pachyconic conch and nearly closed umbilicus. Ornament with coarse and sharp radial riblets and delicate spiral lines between the riblets.

Included species. - decens: Druzeticia decens gen. et sp. nov.; Serbia.

Discussion. - This new enigmatic genus can at current state and without knowledge of the suture line not be attributed to any of the Carboniferous ammonoid families. In the conch shape and ornament, there are some superficial similarities to the families Prionoceratidae and Goniatitidae.

\section{Druzeticia decens sp. nov. \\ Figure 27}

Holotype. - Specimen MB.C.25670.1, illustrated in Fig. 27A.

Type locality and horizon. - Milivojevića Kamenjar site in Družetić (NW Serbia); sample 2009-DRZ2, Ubites filipovici horizon, Entogonites Genus Zone.

Material. - 83 specimens with conch diameters up to $10 \mathrm{~mm}$.

Etymology. - After the Latin decens (= graceful), because of the small, nicely ornamented conch.

Diagnosis. - As for the genus.

Description. - Holotype MB.C.25670.1 (Fig. 27A) is the best of the numerous specimens and it is, with $9 \mathrm{~mm}$ conch diameter, one of the largest individuals. It is a pachyconic conch $(\mathrm{ww} / \mathrm{dm} \sim 0.73$ ) with a nearly closed umbilicus (uw/dm $\sim 0.08$ ). The conch is thickest near the umbilicus, from where the flanks converge towards the broadly rounded venter. The shell ornament consists of two elements, (1) rather coarse riblets, which have a weakly protracted but otherwise linear direction on the flank and form a low and wide ventral projection and (2) very fine spiral lines, which are visible between the riblets and stand in distance of about $0.5 \mathrm{~mm}$. The shell surface shows two constrictions, which in their course largely follow the growth lines.

The material shows some variability with respect to the thickness of the conch. Paratypes MB.C.25670.2 (Fig. 27B) and MB.C.25670.3 (Fig. 27C) have, at the same diameter, a more slender conch (ww/dm $\sim 0.55)$, but differences may 


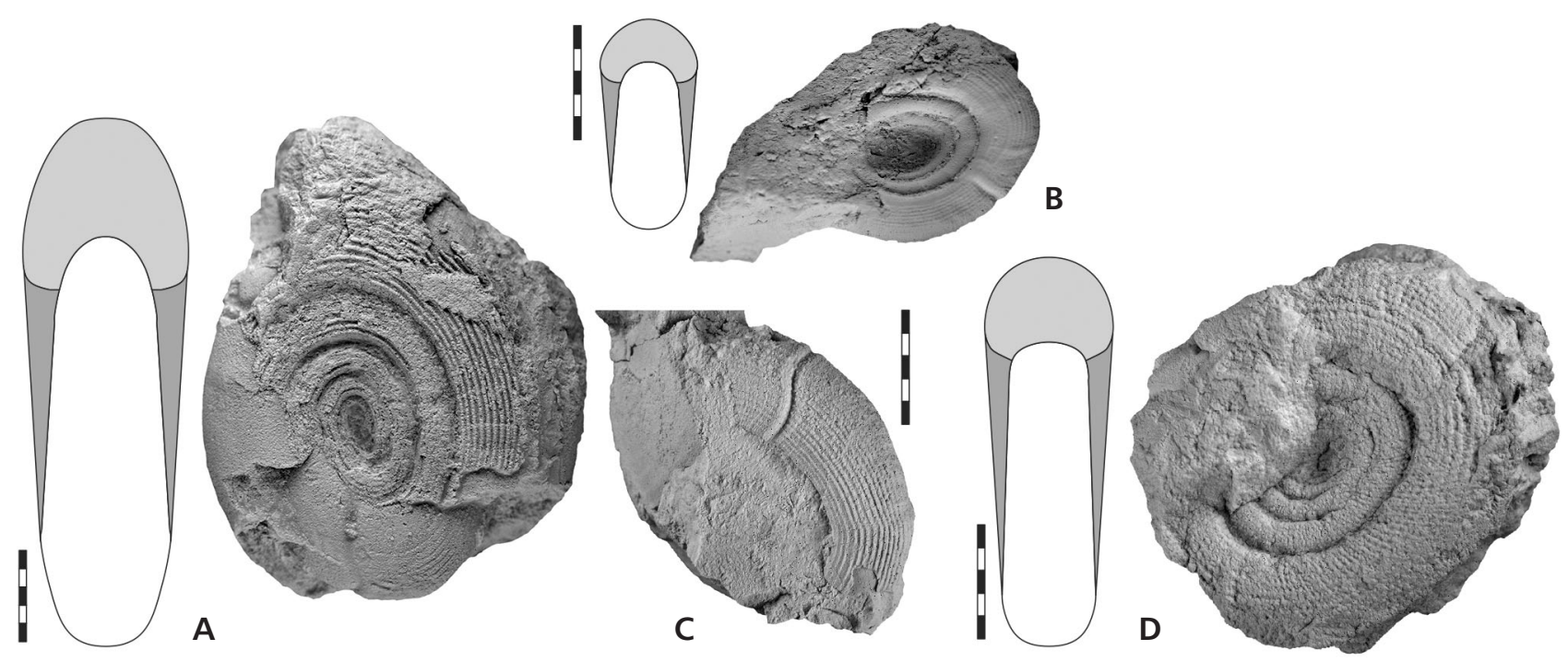

Figure 26. Representatives of the family Rhymmoceratidae from Družetić; lateral and dorsal views. • A - Ophilyroceras tersum Ruzhencev \& Bogoslovskaya, 1971; specimen MB.C.25702.1 from sample 2009-C; × 2. B - Ophilyroceras tersum Ruzhencev \& Bogoslovskaya, 1971; specimen MB.C.25702.2 from sample 2009-C; × 2.5. • C - Ophilyroceras tersum Ruzhencev \& Bogoslovskaya, 1971; specimen MB.C.25732 from loose block 2012-16; × 2.5. •D - Rhymmoceras gracilentum Ruzhencev, 1958; specimen MB.C.25752 from float; × 2.5 .
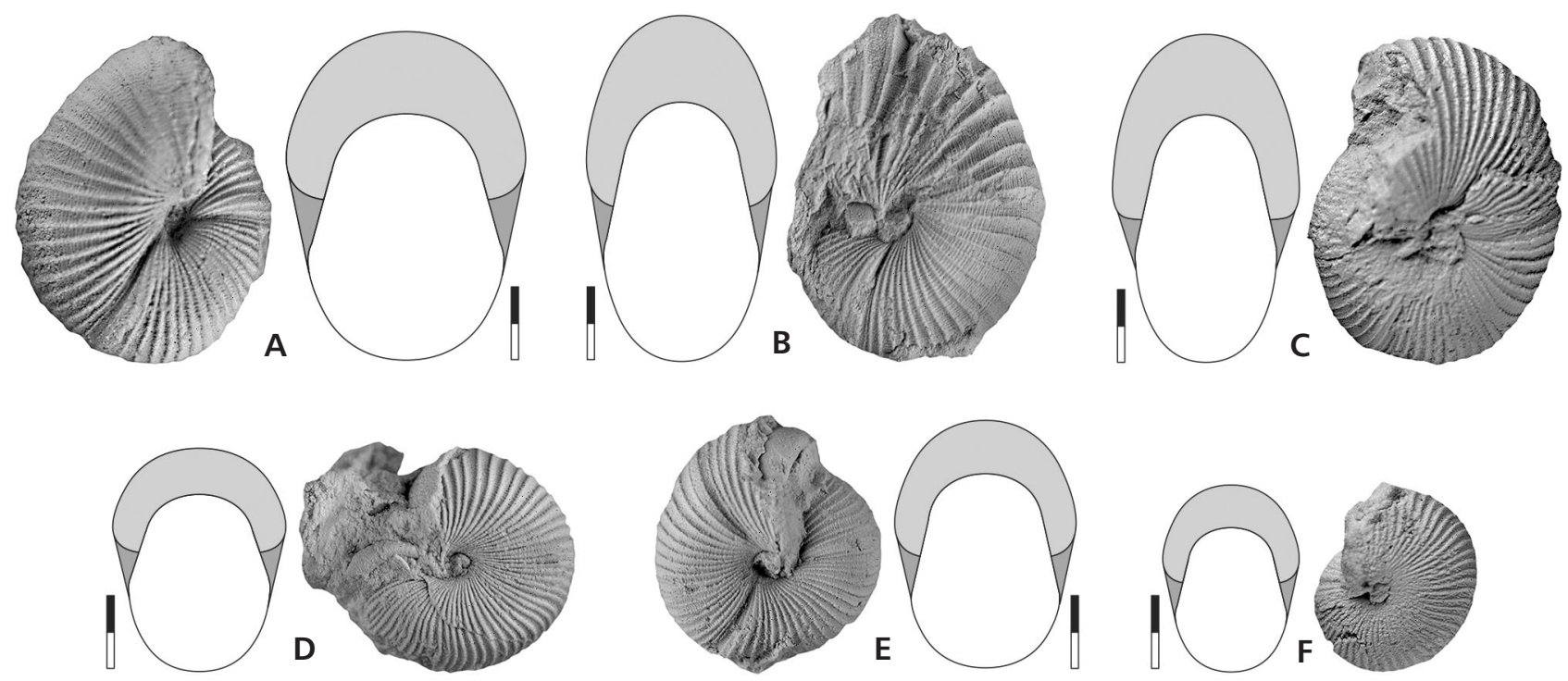

Figure 27. Druzeticia decens sp. nov., lateral and dorsal views; all from Družetić, sample 2009-DRZ2; all × 4. • A - holotype MB.C.25670.1. - B - paratype MB.C.25670.2. $・$ C - paratype MB.C.25670.3. D - paratype MB.C.25670.4. • E - paratype MB.C.25670.5. • F - paratype MB.C.25670.6.

also be caused by deformation. However, the two specimens show also variability in the strength of the riblets; in paratype MB.C.25670.3 they are much finer and more densely spaced that in the holotype and paratype MB.C.25670.2. Both specimens show one constriction.

The smaller paratypes MB.C.25670.4 and MB.C.25670.5 (Fig. 27D, E) with about $7 \mathrm{~mm}$ diameter are stout with an extremely narrow umbilicus. Both possess fine riblets, which in their course are more strongly bent forward in paratype MB.C.25670.5. Specimen
MB.C.25670.4 does not show constrictions, but MB.C. 25670.5 has three constrictions spaced in distances of 120 degrees.

The smallest specimens have a conch diameter of $3 \mathrm{~mm}$; they do not significantly differ in their morphology from the larger ones, except for a slightly wider umbilicus.

Remarks. - The new species does not closely resemble any known ammonoid species. Unfortunately, a suture line could not be seen in the material, and hence a clear 

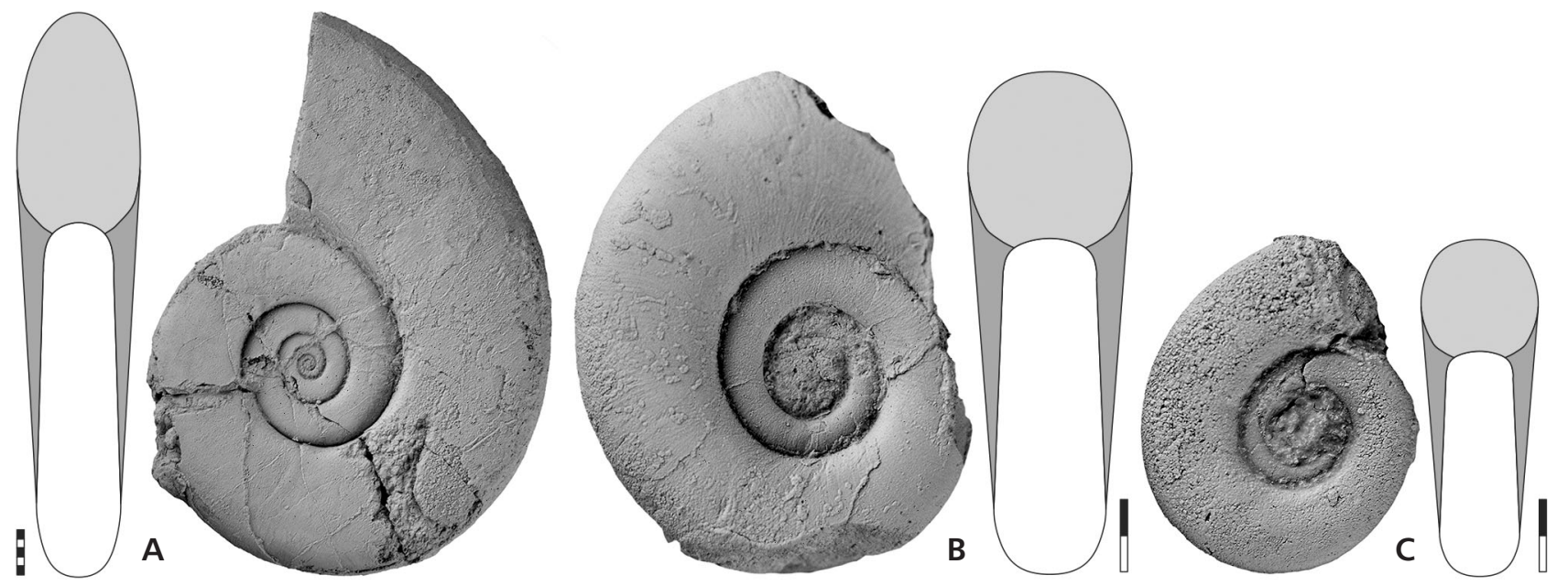

Figure 28. Prolecanites stevanovici sp. nov. from Družetić; lateral and dorsal views. • A - holotype MB.C.25657.1 from sample $2012-D R Z 2 ; \times 1$. - B - paratype MB.C.25673.1 from sample 2009-DRZ2; × 4. • C - paratype MB.C.25637 from block 2010-DRZ1; × 4.

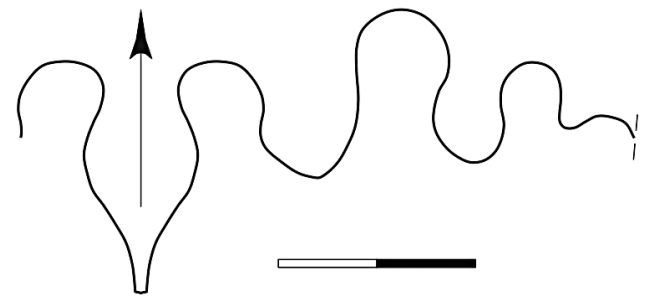

Figure 29. Prolecanites stevanovici sp. nov.; suture line of specimen MB.C.25683.1 from Družetić, sample 2009-DRZ2, $4.2 \mathrm{~mm} w w, 4.5 \mathrm{~mm}$ wh; $\times 10.0$.
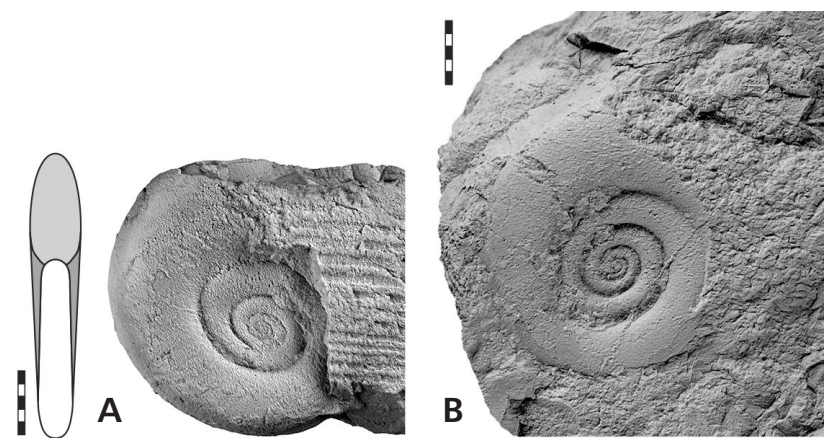

Figure 30. Dombarocanites catillus Ruzhencev \& Bogoslovskaya, 1971 from Družetić; lateral and dorsal views; all $\times 1.5$. $\bullet A-$ specimen MB.C.25747 from float. • B - specimen MB.C.25689 from loose block 2009-B.

attribution of the new species to an ammonoid family is not possible.

Order Prolecanitida Miller \& Furnish, 1954

Suborder Prolecanitina Miller \& Furnish, 1954

Superfamily Prolecanitaceae Hyatt, 1884

Family Prolecanitidae Hyatt, 1884

\section{Genus Prolecanites Mojsisovics, 1882}

Prolecanites stevanovici sp. nov. Figures 28, 29

1962 Metacanites chancharensis (Ruzhencev). - Kullmann in Stevanović \& Kullmann, p. 103, pl. 4, fig. 5 (only).

Holotype. - Specimen MB.C.25657.1; illustrated in Fig. 28A.

Type locality and horizon. - Milivojevića Kamenjar section, Družetić (NW Serbia); from sample 2012-DRZ2, Ubites filipovici horizon, Entogonites Genus Zone.

Material. - 78 newly collected specimens up to $62 \mathrm{~mm}$ conch diameter; also three specimens in the Natural History Museum, Belgrade.

Etymology. - Named after Petar Stevanović (1914-1999) who discovered the fossil locality.

Description. - Holotype MB.C.25657.1 is a deformed but otherwise rather well-preserved specimen of $62 \mathrm{~mm}$ diameter (Fig. 28A), in which the conch proportions can be estimated as follows (without deformation of the last volution): the conch is extremely discoidal and subevolute (ww/dm $\sim 0.22$, uw/dm $\sim 0.40$ ) with a compressed whorl profile (ww/wh $\sim 0.60)$ and rapidly expanding whorls (WER 2.50). The whorl cross section is compressed and oval in the penultimate whorl; it becomes laterally flattened with subparallel flanks in the last volution, where the umbilical wall is steeper. The shell appears to be smooth, but fine convex growth lines are visible in the inner whorls. 
Figure 31. Praedaraelites aktubensis Ruzhencev, 1949 from Družetić; lateral and dorsal views; all $\times 1.5$. $\bullet \mathrm{A}-$ specimen MB.C. 25750 from float. $-\mathrm{B}$ - specimen MB.C.25737.1 from loose block 2012-20. - C - specimen BEO600-551.73:592-455.

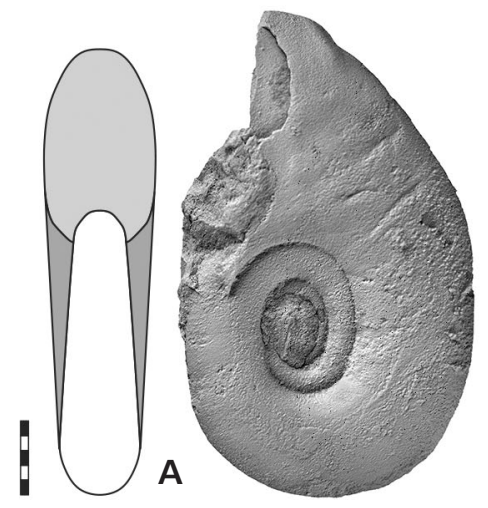

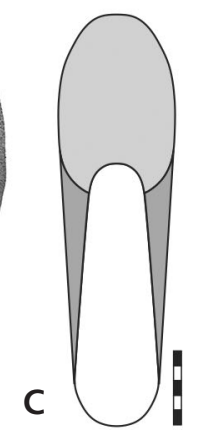

Smaller specimens such as paratypes MB.C.25673.1 (Fig. 28B) with $13 \mathrm{~mm}$ conch diameter and MB.C.25637 (Fig. 28C) with $10 \mathrm{~mm}$ conch diameter have similar conch proportions but possess a wider whorl profile (ww/wh 0.90 and 1.00 , respectively). The first specimen shows the well-preserved shell ornament, which consists of fine growth lines extending with a projection on the flank and a wide and very shallow ventral sinus.

A suture line can be seen in the small specimen MB.C.25683.1 at $4.5 \mathrm{~mm}$ whorl height (Fig. 29). The dominant sutural element is the very large and pouched E lobe, which is much deeper than the slightly pouched, blunt A lobe. The lateral lobe is pouched and continuously rounded.

Discussion. - Obviously, the new species is, with a ww/dm ratio of about 0.22 and a ww/wh ratio of about 0.60 at $40 \mathrm{~mm}$ conch diameter, the most slender species of the genus. The species $P$. discoides (Foord \& Crick) for instance shows ratios of 0.30 and $0.80-0.90$ in this growth stage, similar ratios can be seen in most of the other species of Prolecanites.

\section{Genus Dombarocanites Ruzhencev, 1949}

\section{Dombarocanites catillus Ruzhencev \& Bogoslovskaya, 1971}

Figure 30

1971 Dombarocanites catillus sp. nov.; Ruzhencev \& Bogoslovskaya, p. 135, pl. 1, figs 8, 9.

Material. - Six rather poorly preserved specimens from new collections; they range between 12 and $30 \mathrm{~mm}$ in diameter.

Description. - Specimen MB.C. 25747 belongs to the better preserved specimens; it has $30 \mathrm{~mm}$ conch diameter and is extremely discoidal ( $\mathrm{ww} / \mathrm{dm} \sim 0.26$ ) with a rather wide umbilicus (uw/dm $\sim 0.43$ ). The whorl profile is compressed and the shell surface appears to be smooth (Fig. 30A).
Family Daraelitidae Tchernow, 1907

\section{Genus Praedaraelites Schindewolf, 1926}

Praedaraelites aktubensis Ruzhencev, 1949

Figure 31

1949 Praedaraelites aktubensis sp. nov.; Ruzhencev, p. 740, text-figs $1 \mathrm{i}-\mathrm{n}, 2 \mathrm{e}, 3 \mathrm{c}$.

1962 Metacanites chancharensis (Ruzhencev). - Kullmann in Stevanović \& Kullmann, p. 103, pl. 4, fig. 4 (only).

1971 Epicanites aktubensis (Ruzhencev). - Ruzhencev \& Bogoslovskaya, p. 132, pl. 1, figs 10-13, pl. 2, figs 1, 2.

Material. - Five rather strongly deformed specimens of 20 to $30 \mathrm{~mm}$ conch diameter from new collections and about five specimens in the Natural History Museum, Belgrade.

Description. - MB.C.25737.1 is a poorly preserved deformed specimen with $32 \mathrm{~mm}$ diameter (Fig. 31B). The conch is extremely discoidal and subinvolute (uw/dm $\sim 0.25$ ) with oval, compressed whorl cross section. The shell surface is smooth.

Specimen BEO600-551.73:592-455 (Kullmann in Stevanović \& Kullmann 1962, pl. 4, fig. 4) is a rather well-preserved individual with $27 \mathrm{~mm}$ conch diameter (Fig. 31C). It is extremely discoidal (ww/dm 0.30) and subevolute $(\mathrm{uw} / \mathrm{dm} \sim 0.32)$ with a high aperture $(\mathrm{WER} \sim$ 2.35). The specimen is almost entirely covered with nearly smooth shell and the suture line is not visible.

Specimen MB.C.25750 (Fig. 31A) is a specimen of about $30 \mathrm{~mm}$ conch diameter, of which particularly the body chamber is strongly deformed. It is extremely discoidal and subevolute $(\mathrm{ww} / \mathrm{dm} \sim 0.30 ; \mathrm{uw} / \mathrm{dm} \sim 0.33$ ) with a compressed oval whorl profile at $25 \mathrm{~mm}$ diameter. The shell surface appears to be smooth.

Remarks. - Parts of the suture line are only visible in 


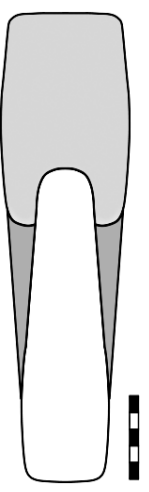

A

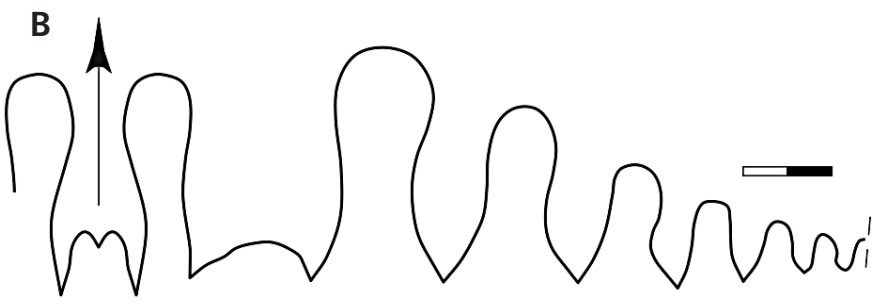

Figure 32. Uralopronorites mirus Librovitch, 1949 from Družetić ("lower horizon" of Stevanović \& Kullmann 1962); dorsal view and suture line of specimen BEO600-551.73:592-463. • A - dorsal view; $\times 1$ 1.5. $\bullet$ B suture line, at $7.6 \mathrm{~mm} \mathrm{ww}, 13.4 \mathrm{~mm}$ wh; $\times 4.0$. specimen MB.C.25709 they show a serrated adventive lobe and an inflated ventrolateral saddle. The absence of suture lines in the other specimens may prevent clear assignment to the genus Praedaraelites, but the whorl expansion rate of 2.35 (about 2.80 in Dombarocanites chancharensis at the same conch diameter) and the combination of a comparatively narrow umbilicus with a rather wide whorl profile and a rather high embracing rate of the whorls speaks for assignment to this genus rather than in Dombarocanites.

Superfamily Medlicottiaceae Karpinsky, 1889 Family Pronoritidae Frech, 1901

\section{Genus Uralopronorites Librovitch, 1949}

\section{Uralopronorites mirus Librovitch, 1949}

Figure 32

1949 Uralopronorites mirus sp. nov.; Librovitch in Ruzhencev, p. 63, pl. 1, figs 10-15, text-figs 24, 25.

1962 Pronorites uralensis uralensis Karpinsky. - Kullmann in Stevanović \& Kullmann, p. 107, pl. 4, fig. 6, text-fig. $7 \mathrm{~b}$.

1971 Uralopronorites mirus Librovitch. - Ruzhencev \& Bogoslovskaya, p. 145, pl. 3, figs 3-5.

Material. - Three poorly preserved fragments from new collections; their species attribution is not clear. There are additionally about eight specimens in the Natural History Museum, Belgrade.

Description. - Specimen BEO600-551.73:592-463 (Kullmann in Stevanović \& Kullmann 1962, pl. 4, fig. 6) is incomplete; the conch is thinly discoidal (ww/dm 0.40) and subinvolute (uw/dm 0.17) at $25 \mathrm{~mm}$ diameter. The flanks of the specimen are flat and separated from the nearly flat venter by a subangular ventrolateral margin (Fig. 32A). Five successive suture lines show a very narrow external lobe, a deep and pouched, asymmetric adventive lobe that is deeper than the lateral lobe and five further lobes on the flank (Fig. 32B).

\section{Acknowledgements}

We particularly acknowledge Divna Jovanović, Ivan Filipović (both Belgrade) and Matevž Novak (Ljubljana) for their intense assistance in the field. Aleksandra Stevanović made the collections of the Natural History Museum, Belgrade available for study. Dieter Korn acknowledges the Deutsche Forschungsgemeinschaft (DFG project Ko1829/8-1) for financial support. Special thanks to J. Evelin Stenzel (Berlin) for preparation and Ana Suchocka (Berlin) for photography of the specimens. We further thank Sonny A. Walton (Potsdam) for checking the language of the manuscript and Claude Monnet (Lille) and an anonymous reviewer for constructive suggestions.

\section{References}

Bisat, W.S. 1924. The Carboniferous goniatites of the north of England and their zones. Proceedings of the Yorkshire Geological Society 20, 40-124. DOI 10.1144/pygs.20.1.40

Bisat, W.S. 1928. The Carboniferous goniatite zones of England and their continental equivalents. Compte Rendu Congrès International de Stratigraphie et de Géologie du Carbonifère (Heerlen 1927), 117-133.

Bisat, W.S. 1932. On some lower Sabdenian goniatites. Transactions of the Leeds Geologist Association 5, 27-36.

BisAt, W.S. 1952. The goniatite succession at Cowdale Clough, Barnoldswick, Yorkshire. Transactions of the Leeds Geologist Association 6(4), 155-181.

Edwards, F.E. 1849. A monograph of the Eocene Mollusca. Part I. Cephalopoda. Transactions of the Palaeontographical Society 2, 1-56.

Filipović, I. (ed.) 1995. The Carboniferous of Northwestern Serbia. Rasprave Geološkog zavoda "Gemini" 25, 1-104. [in Serbian and English]

Foord, A.H. 1903. Monograph of the Carboniferous Cephalopoda of Ireland, Part V, Containing the families Glyphioceratidae (concluded) and Prolecanitidae, with title-page and index. Transactions of the Palaeontographical Society 57, $147-234$

GoRdon, M.J. 1957. Missisippian Cephalopods of Northern and Eastern Alaska. U.S. Geological Survey Professional Papers 283, 1-61.

Hyatt, A. 1883-1884. Genera of fossil cephalopods. Proceedings of the Boston Society of Natural History, 253-338.

Hyatт, A. 1900. Tetrabranchiate Cephalopoda, 502-604. In 
ZitTel, K.A. von \& EASTMAn, C.R. (eds) Text-book of palaeontology, Volume 1. $1^{\text {st }}$ edition. Macmillan and Co., London.

KaRPINSKY, A.P. 1889. Über die Ammoneen der Artinsk-Stufe und einige mit denselben verwandte carbonische Formen. Mémoires de l'Académie Impériale des Sciences de St.-Pétersbourg, VIIe Série 37(2), 1-104.

KitTL, E. 1904a. Entogonites, eine Cephalopodengattung aus dem bosnischen Kulm. Verhandlungen der Kaiserlichköniglichen geologischen Reichsanstalt 14, 322.

KitTL, E. 1904b. Geologie der Umgebung von Sarajewo. Jahrbuch der Kaiserlich-königlichen geologischen Reichsanstalt 53 (for 1903), H. 4, 515-748.

Korn, D. 1988. Die Goniatiten des Kulmplattenkalkes (Cephalopoda, Ammonoidea; Unterkarbon; Rheinisches Schiefergebirge). Geologie und Paläontologie in Westfalen 11, 1-293.

Korn, D. 1990. Weitere Goniatiten aus dem Ober-Visé des Sauerlandes (Cephalopoda, Ammonoidea; Unterkarbon; Rheinisches Schiefergebirge). Geologie und Paläontologie in Westfalen 15, 11-69.

Korn, D., Jovanović, D., Novak, M. \& Sudar, M.N. 2010 b. Early late Visean ammonoid fauna from the Jadar Block (NW Serbia). Geologica carpathica 61(5), 355-364.

Korn, D. \& Klug, C. 2002. Fossilium Catalogus I: Animalia. Ammoneae Devonicae. 375 pp. Backhuys, Leiden.

Korn, D., KLUG, C. \& MAPES, R.H. 1999. Visean and Early Namurian ammonoids from the Tafilalt (Eastern Anti-Atlas, Morocco). Abhandlungen der Geologischen Bundesanstalt 54, 345-375.

Korn, D., Klug, C. \& MAPES, R.H. 2005. The Lazarus ammonoid family Goniatitidae, the tetrangularly coiled Entogonitidae, and Mississippian biogeography. Journal of Paleontology 79, 356-365.

DOI 10.1666/0022-3360(2005)079<0356:TLAFGT>2.0.CO;2

Korn, D. \& Price, J.D. 1987. Taxonomy and phylogeny of the Kosmoclymeniinae subfam. nov. (Cephalopoda, Ammonoidea, Clymeniida). Courier Forschungsinstitut Senckenberg 92, 5-75.

Korn, D., Sudar, M.N., NovaK, M. \& Jovanović, D. 2010a. The palaeogeographic position of the Jadar Block (Vardar Zone, NW Serbia) in the Early Carboniferous. Scientific Annals, School of Geology, Aristotle University of Thessaloniki, Proceedings of the XIX Carpathian-Balkan Geological Association Congress, Thessaloniki, Greece, Special volume 100, 141-147.

Korn, D. \& Titus, A.L. 2011. Goniatites Zone (middle Mississippian) ammonoids of the Antler Foreland Basin (Nevada, Utah). Bulletin of Geosciences 86(1), 107-196.

DOI 10.3140/bull.geosci.1242

Korn, D., Titus, A.L., Ebbighausen, V., Mapes, R.H. \& Sudar, M.N. 2012. Early Carboniferous (Mississippian) ammonoid biogeography. Geobios 45, 67-77. DOI 10.1016/j.geobios.2011.11.013

Kostic-Podgorska, V. 1958. La faune et biostratigraphie des couches paleozoïques dans les environs de Praca (Bosnie). Geološki glasnik BiH (Sarajevo) 4, 1-220.

Kullmann, J., Wagner, R.H. \& Winkler Prins, C. 2007. Significance for international correlation of the Perapertú Formation in northern Palencia, Cantabrian Mountains. Tectonic/stratigraphic context and description of Mississippian and Upper Bashkirian goniatites. Revista Española de Paleontología 22, 127-145.

Librovitch, L.S. 1938. Kamennougolnye ammonii s yuzhnogo ostrova Novoy Zemli. Trudy Arkticheskogo nauchnoissledovatel'skogo instituta 101, 47-107.

LiBrovitch, L.S. 1941. Otryad Ammonoidea, 137-153. In LiBrovitch, L.S. (ed.) Atlas rukovodyashchikh form isko- paemykh faun SSSR, t. IV. Nizhniy otdel kamennougolnoy sistemy. Tsentralnyi nauchno-issledovatel'skii geologo-razvedochnyi institut, Leningrad.

LiBROVITCH, L.S. 1957. O nekotorykh novykh gruppakh goniatitov iz kamennougolnykh otlozheniy SSSR. Ezhegodnik Vsesoyuznogo paleontologicheskogo obshchestva 16, 246-273.

Miller, A.K. \& Furnish, W.M. 1940. Studies on Carboniferous ammonoids: parts 1-4. Journal of Paleontology 14, 356-377.

Miller, A.K. \& Furnish, W.M. 1954. The classification of the Paleozoic ammonoids. Journal of Paleontology 28, 685-692.

Mojsisovics, E. v. M. 1882. Die Cephalopoden der mediterranen Triasprovinz. Abhandlungen der Kaiserlichen und königlichen geologischen Reichsanstalt 10, 1-322.

Münster, G. GraF ZU 1839. Nachtrag zu den Clymenien des Fichtelgebirges. Beiträge zur Petrefactenkunde 1, 35-43.

Nicolaus, H.-J. 1963. Zur Stratigraphie und Fauna der crenistria-Zone im Kulm des Rheinischen Schiefergebirges. Beihefte zum Geologischen Jahrbuch 53, 1-246.

RAUSER-TSChERnOUSSOWA, D.M. 1928. O nekotorykh kamennougolnykh ammonitakh Fergany. Izvestiya Assotsiatsii issledovaniya institutov pri 1 Moskosvskovo universiteta, fiziko-matematicheskiy fakultet 1, 164-178.

RENZ, C. 1910. Stratigraphische Untersuchungen im griechischen Mesozoikum und Palaeozoikum. Jahrbuch der Kaiserlichen und königlichen geologischen Reichsanstalt 60, 421-636.

RuZHENCEv, V.E. 1938. Ammonei Sakmarskogo yarusa i ikh stratigraficheskoe znachenie. Problemy paleontologii 4, 187-285.

RuzhenCEv, V.E. 1947. Novyy rod iz semeystva Cheiloceratidae v Namyurskikh otlozheniyakh Urala. Doklady Akademii nauk SSSR 57(3), 281-284.

Ruzhencev, V.E. 1949. Sistematika i evolyutsia semeystv Pronoritidae Frech i Medlicottiidae Karpinsky. Trudy Paleontologicheskogo instituta Akademii nauk SSSR 19, 1-206.

RuZHENCEV, V.E. 1950. Verkhnekamennougolnye ammonity Urala. Trudy Paleontologicheskogo instituta Akademii nauk SSSR 29, 1-220.

RuZHENCEV, V.E. 1956. O nekotorykh novykh roday ammonoidey. Doklady Akademii nauk SSSR 107, 158-161.

RuZHENCEv, V.E. 1957. Filogeneticheskaya sistema paleozoiskikh ammonoidei. Byulleten' Moskovskogo obshchestva ispytatelei prirody, Otdelenie geologii 32(2), 49-64.

RuZHENCEv, V.E. 1958. Dva novykh roda goniatitov v nizhnem Namyure yuzhnogo Urala. Doklady Akademii nauk SSSR 122, 293-296.

Ruzhencev, V.E. \& Bogoslovskaya, M.F. 1970. Reviziya nadsemeystva Goniatitaceae. Paleontologicheskiy zhurnal 1970(4), 52-65.

RuZHENCEV, V.E. \& BogosLovsKaya, M.F. 1971. Namyurskiy etap v evolyutsii ammonodey. Rannenamyurskiye ammonoidei. Trudy Paleontologicheskogo instituta Akademii nauk SSSR 133, 1-382.

SCHINDEwolf, O.H. 1923. Beiträge zur Kenntnis des Paläozoikums in Oberfranken, Ostthüringen und dem Sächsischen Vogtlande. I. Stratigraphie und Ammoneenfauna des Oberdevons von Hof a.S. Neues Jahrbuch für Mineralogie, Geologie und Paläontologie, Beilage-Band 49, 250-357, 393-509.

SCHINDEwolf, O.H. 1926. Beiträge zur Kenntnis der Cephalopodenfauna des oberfränkisch-ostthüringischen Unterkarbons. Senckenbergiana 8, 63-96.

SCHмIDT, H. 1941. Eine neue Fauna mit Pericyclus von Riefensbeek im Harz. Jahrbuch der Reichsstelle für Bodenforschung 60, 148-156.

SMITH, J.P. 1896. Marine fossils from the Coal Measures of Ar- 
kansas. Proceedings of the American Philosophical Society $35,214-285$.

Stevanović, P. 1962. Cephalopodenkalke der Namur stufe im Ubtal bei Družetić (W. Serbien). Zapisnici Srpskog geološkog društva za 1958. i 1959. godinu (Zbor 10. XII 1958), 105-110. [in Serbian, German summary]

Stevanović, P. \& Kullmann, J. 1962. Namurian bei Družetic im westlichen Serbien und seine Goniatitenfauna. Glasnik Prirodnjačkog muzeja (Bulletin Muséum d'Histoire Naturelle Belgrade) A 1962, 16-17, 45-112.
TChernow, A.A. 1907. Artinsky yarus. I. Ammonei basseynov Yayvy, Kos'vy i Chusovoy. 1. Vvednie. Obzor issledovannoy mestnosti. Prolecanitidae. Byulleten' Moskovskogo obshchestva ispytatelei prirody 20, 270-401.

WedEKIND, R. 1914. Beiträge zur Kenntnis der Oberkarbonischen Goniatiten. Mitteilungen aus dem Museum der Stadt Essen für Natur- und Völkerkunde 1, 1-22.

Wedekind, R. 1918. Die Genera der Palaeoammonoidea (Goniatiten). Mit Ausschluß der Mimoceratidae, Glyphioceratidae und Prolecanitidae. Palaeontographica 62, 85-184.

\section{Appendix}

List of co-occurrences of ammonoid species in samples and loose blocks from new collections.

\begin{tabular}{|c|c|c|c|c|c|c|c|c|c|c|c|c|c|c|c|c|c|c|c|c|c|c|c|c|c|c|c|c|}
\hline & & 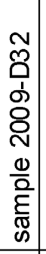 & 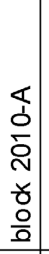 & 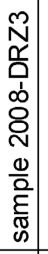 & 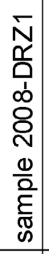 & 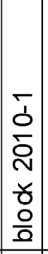 & 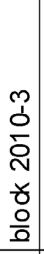 & 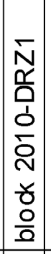 & 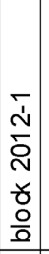 & 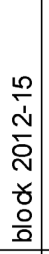 & 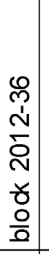 & 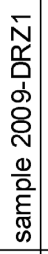 & 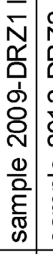 & 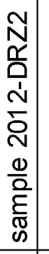 & 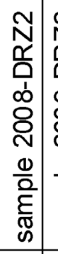 & 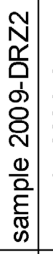 & 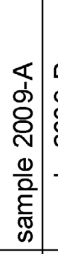 & 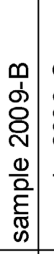 & 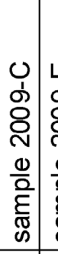 & 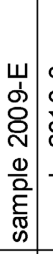 & 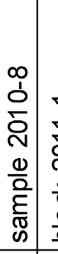 & 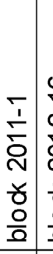 & 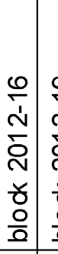 & 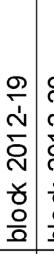 & 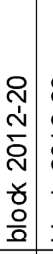 & 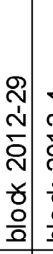 & 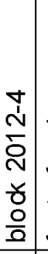 & 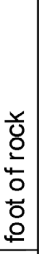 \\
\hline Linguaclymenia & similis & & 1 & & & & & & & & & & & & & & & & & & & & & & & & & \\
\hline kosmoclymeniid & sp. & 1 & & & & & & & & & & & & & & & & & & & & & & & & & & \\
\hline Cymaclymenia & sp. & 1 & & & & & & & & & & & & & & & & & & & & & & & & & & \\
\hline Imitceras & sp. & & & 2 & & & & & & & & & & & & & & & & & & & & & & & & \\
\hline Beyrichoœratoides & sp. & & & & 1 & & & & & & & & & & 6 & 7 & & & & & & & & & & & & \\
\hline Bollandites & sp. & & & & & & & 1 & & & & & & & & & & & & & & & & & & & & \\
\hline Bollandoœras & sp. & & & & & 9 & & & & 1 & & & 2 & & & & & & & & & & & & & & & \\
\hline Beyrichoœras & crenistriatoide & & & & & & & & & & 3 & 1 & 8 & & & & & & & & & & & & & & & \\
\hline Beyrichoœras & jadarense & & & & & & & & & & & & & & 31 & 10 & & & & & & & & & & & & \\
\hline Calygirtyoceras & sp. & & & & & & & & & & & & & & 1 & & & & & & & & & & & & & \\
\hline Entogonites & grimmeri & & & & 13 & 5 & 3 & & 1 & & 2 & 2 & 12 & & & 2 & & & & & & & & & & & & \\
\hline Entogonites & sp. & & & & 7 & 4 & & & & & & & & & & & & & & & & & & & & & & \\
\hline Entogonites & tetragonus & & & & 49 & 31 & & 1 & 5 & 1 & 27 & 16 & 18 & 1 & & & & & & & & & & & & & & \\
\hline Entogonites & senbicus & & & & 5 & 1 & & 1 & & & & & 3 & & & & & & & & & & & & & & & \\
\hline Ubites & filipovici & & & & 4 & & & & & & & & & 1 & 496 & 67 & & & & & & & & & & & & \\
\hline Ubites & novaki & & & & 2 & & & 2 & & & 1 & & & & & 1 & & & & & & & & & & & & \\
\hline Ubites & divnae & & & & & & & 1 & & & 1 & & & & 13 & 6 & & & & & & & & & & & & \\
\hline Nomismoceras & sp. & & & & 5 & & & & & & & & 1 & & 1 & & & & & & & & & & & & & \\
\hline Druzeticia & decens & & & & & & & & 1 & & & 1 & & 1 & \begin{tabular}{l|l}
32 & 4 \\
\end{tabular} & 48 & & & & & & & & & & & & \\
\hline Prolecanites & ste vanovici & & & & 19 & 17 & 2 & 1 & & & 5 & 10 & 14 & 2 & 1 & 7 & & & & & & & & & & & & \\
\hline Pronorites & sp. & & & & & & & & & & & & & 1 & & 1 & & & & & & & & & & & & \\
\hline indet. & sp. & & & & 45 & 4 & & & & & & & & & & 23 & & & & & & & & & & & & \\
\hline Innoceras & arcuatum & & & & & & & & & & & & & & & & 1 & 1 & & & & & & & & & 1 & \\
\hline Hypergoniatites & sp. & & & & & & & & & & & & & & & & & & & & & & & & & 1 & & \\
\hline Dombarites & falcatoides & & & & & & & & & & & & & & & & & & 2 & 1 & & 5 & & & & 1 & 1 & \\
\hline Dombarites & liratus & & & & & & & & & & & & & & & & 1 & & 1 & & & & 2 & & & & & \\
\hline Platygoniatites & molaris & & & & & & & & & & & & & & & & & & & & & 1 & & & & & & \\
\hline Platygoniatites & omniliratus & & & & & & & & & & & & & & & & & & 2 & & & & & & & & & 1 \\
\hline Lyrogoniatites & sp. & & & & & & & & & & & & & & & & & & & & & & & 1 & & & & \\
\hline Lyrogoniatites & tener & & & & & & & & & & & & & & & & & & 2 & & & & & & & & & \\
\hline Pachylyroceras & sp. & & & & & & & & & & & & & & & & & & 1 & & & & & 1 & & & & \\
\hline Neoglyphioceras & baccans & & & & & & & & & & & & & & & & & & 14 & 9 & & 1 & & & & & & 1 \\
\hline Neoglyphioceras & litvinovichae & & & & & & & & & & & & & & & & & & & & & & & & 1 & & & \\
\hline Neoglyphioceras & sp. & & & & & & & & & & & & & & & & & & 1 & & & 3 & & & & & & \\
\hline Lusitanites & concavus & & & & & & & & & & & & & & & & & & & & & 3 & & & & & & 1 \\
\hline Ophilyroceras & tersum & & & & & & & & & & & & & & & & & & 2 & & 1 & & 1 & & & & & \\
\hline Dombarocanites & catillus & & & & & & & & & & & & & & & & & 3 & 1 & & & 1 & & & & & & \\
\hline Praedaraelites & aktubensis & & & & & & & & & & & & & & & & & & & & 1 & & & & 1 & & & \\
\hline Uralopronorites & minus & & & & & & & & & & & & & & & & & & & & 1 & & & & & & & \\
\hline
\end{tabular}

